\title{
How weather events modify aerosol particle size distributions in the Amazon boundary layer
}

\author{
Luiz A. T. Machado ${ }^{1,2}$, Marco A. Franco ${ }^{2}$, Leslie A. Kremper ${ }^{1}$, Florian Ditas ${ }^{1, a}$, Meinrat O. Andreae ${ }^{1,3,4}$, \\ Paulo Artaxo $^{2}$, Micael A. Cecchini ${ }^{2}$, Bruna A. Holanda ${ }^{1}$, Mira L. Pöhlker ${ }^{1,6,7}$, Ivan Saraiva ${ }^{5}$, \\ Stefan Wolff ${ }^{1}$, Ulrich Pöschl ${ }^{1}$, and Christopher Pöhlker ${ }^{1}$ \\ ${ }^{1}$ Multiphase Chemistry Department, Max Planck Institute for Chemistry, Mainz, Germany \\ ${ }^{2}$ Instituto de Física, Universidade de São Paulo, São Paulo, Brazil \\ ${ }^{3}$ Scripps Institution of Oceanography, University of California San Diego, La Jolla, CA, USA \\ ${ }^{4}$ Department of Geology and Geophysics, King Saud University, Riyadh, Saudi Arabia \\ ${ }^{5}$ Meteorology Division, Sistema de Proteção da Amazônia, Manaus, Brazil \\ ${ }^{6}$ Faculty of Physics and Earth Sciences, Leipzig Institute for Meteorology, \\ University of Leipzig, Leipzig, Germany \\ ${ }^{7}$ Experimental Aerosol and Cloud Microphysics Department, Leibniz Institute \\ for Tropospheric Research, Leipzig, Germany \\ ${ }^{a}$ now at: Hessian Agency for Nature Conservation, Environment and Geology, Wiesbaden, Germany
}

Correspondence: Luiz A. T. Machado (1.machado@mpic.de)

Received: 14 April 2021 - Discussion started: 20 April 2021

Revised: 3 November 2021 - Accepted: 3 November 2021 - Published: 10 December 2021

\begin{abstract}
This study evaluates the effect of weather events on the aerosol particle size distribution (PSD) at the Amazon Tall Tower Observatory (ATTO). This research combines in situ measurements of PSD and remote sensing data of lightning density, brightness temperature, cloud top height, cloud liquid water, and rain rate and vertical velocity. Measurements were obtained by scanning mobility particle sizers (SMPSs), the new generation of GOES satellites (GOES-16), the SIPAM S-band radar and the LAP 3000 radar wind profiler recently installed at the ATTO-Campina site. The combined data allow exploring changes in PSD due to different meteorological processes. The average diurnal cycle shows a higher abundance of ultrafine particles $\left(N_{\mathrm{UFP}}\right)$ in the early morning, which is coupled with relatively lower concentrations in Aitken $\left(N_{\mathrm{AIT}}\right)$ and accumulation $\left(N_{\mathrm{ACC}}\right)$ mode particles. From the early morning to the middle of the afternoon, an inverse behavior is observed, where $N_{\text {UFP }}$ decreases and $N_{\mathrm{AIT}}$ and $N_{\mathrm{ACC}}$ increase, reflecting a typical particle growth process. Composite figures show an increase of $N_{\text {UFP }}$ before, during and after lightning was detected by the satellite above ATTO. These findings strongly indicate a close relationship between vertical transport and deep convective clouds. Lightning density is connected to a large increase in $N_{\mathrm{UFP}}$, beginning approximately $100 \mathrm{~min}$ before the maximum lightning density and reaching peak values around $200 \mathrm{~min}$ later. In addition, the removal of $N_{\mathrm{ACC}}$ by convective transport was found. Both the increase in $N_{\mathrm{UFP}}$ and the decrease in $N_{\mathrm{ACC}}$ appear in parallel with the increasing intensity of lightning activity. The $N_{\mathrm{UFP}}$ increases exponentially with the thunderstorm intensity. In contrast, $N_{\mathrm{AIT}}$ and $N_{\mathrm{ACC}}$ show a different behavior, decreasing from approximately $100 \mathrm{~min}$ before the maximum lightning activity and reaching a minimum at the time of maximum lightning activity. The effect of cloud top height, cloud liquid water and rain rate shows the same behavior, but with different patterns between seasons. The convective processes do not occur continually but are probably modulated by gravity waves in the range of 1 to $5 \mathrm{~h}$, creating a complex mechanism of interaction with a succession of updrafts and downdrafts, clouds, and clear-sky situations.

The radar wind profiler measured the vertical distribution of the vertical velocity. These profiles show that downdrafts are mainly located below $10 \mathrm{~km}$, while aircraft observations during the ACRIDICON-CHUVA campaign had shown maximum concentrations of ultrafine particles mainly above $10 \mathrm{~km}$. Our study opens new sci-
\end{abstract}


entific questions to be evaluated in order to understand the intricate physical and chemical mechanisms involved in the production of new particles in Amazonia.

\section{Introduction}

The Fifth Assessment Report of the Intergovernmental Panel on Climate Change (AR5 of IPCC, 2013) shows that clouds and aerosols contribute the largest uncertainty in our understanding of the Earth's changing energy budget. Aerosols impact climate, clouds and precipitation by the direct and indirect effects. Studies based on observations and modeling have improved knowledge and reduced uncertainties regarding the aerosol direct effect (e.g., Ramanathan et al., 2001; Hansen et al., 1997); see also Haywood and Boucher (2000) for a review of the estimated direct global annual mean radiative forcing. The effects of natural and anthropogenic sources, such as forest fires and urban pollution, on aerosolcloud-precipitation interactions, including cloud invigoration as well as precipitation reduction by increased aerosol loading and the associated effects on cloud microphysics, have been intensely studied (e.g., Albrecht, 1989; Andreae et al., 2004; Rosenfeld, 2018; Twomey and Warner, 1967; Rosenfeld, 1999; Koren et al., 2005; Rosenfeld et al., 2008; Cecchini et al., 2017a; Heikenfeld et al., 2019). In addition, the knowledge about aerosol characteristics, cloud condensation nuclei (CCN), secondary organic aerosol (SOA) and volatile organic compounds (VOCs) has been greatly improved, specifically in the Amazon region (e.g., Pöschl et al., 2010; Pöhlker et al., 2016, 2018; Palm et al., 2018; YáñezSerrano et al., 2020; Holanda et al., 2020; Saturno et al., 2018; Leppla et al., 2021; Schrod et al., 2020). Although these studies have advanced our knowledge of aerosol-cloud interactions, only very few attempts have been made to describe how clouds modify the aerosol properties.

For the Amazon, this topic was recently addressed by two field experiments: Observations and Modeling of the Green Ocean Amazon (GoAmazon2014/5) (Martin et al., 2016, 2017) and ACRIDICON-CHUVA ${ }^{1}$ (Wendisch et al., 2016; Cecchini et al., 2017b; Machado et al., 2018). Gerken et al. (2016) discussed the downward transport of ozone by convective clouds and used the surface equivalent potential temperature $\left(\theta_{\mathrm{e}}\right)$ as a proxy of convective events that produced an increase in ozone concentration at the surface during rainfall events. Wang et al. (2016) analyzed the origin of small aerosol particles in the boundary layer (BL). They found high concentrations of these particles in the free troposphere up to $6 \mathrm{~km}$ and concluded that they were transported

\footnotetext{
${ }^{1}$ Aerosol, Cloud, Precipitation, and Radiation Interactions and Dynamics of Convective Cloud Systems-Cloud Processes of the Main Precipitation Systems in Brazil: A Contribution to Cloud Resolving Modeling and to the Global Precipitation Measurement (GPM)
}

down by convective downdrafts during intense precipitation events. Andreae et al. (2018) showed enhanced concentrations of ultrafine particles in the upper troposphere, which were much higher than in the planetary BL (PBL). They suggested that these particles were produced in the outflow from deep convective events and were returned to the surface by convective downdrafts. Williamson et al. (2019), using aircraft measurements over the Pacific and Atlantic oceans, also observed new particle formation in the tropical upper troposphere and suggested that these particles descend towards the lower troposphere, where they can act as CCN, modifying cloud properties.

This study evaluates the effect of weather events on particle number size distribution (PSD) changes, combining satellite and radar data with measurements from two scanning mobility particle sizers (SMPSs) at 60 and $325 \mathrm{~m}$ height at the Amazon Tall Tower Observatory (ATTO) (Andreae et al., 2015). The PSD data are analyzed for the main cycles and cloud characteristics in the central Amazonian region, highlighting the relationship between lightning storms and changes in PSD. This study explores changes in PSD by the atmosphere's seasonal and diurnal cycles and intradiurnal variability, and it evaluates the relationships between PSD and lightning, rainfall, cloud top height, cloud liquid water, and brightness temperature during the dry and wet seasons. These analyses will help to understand the new particle formation observed during convective events.

\section{Data and methods}

This study combines different types of datasets, all colocated at the ATTO site, which has been described in detail by Andreae et al. (2015). The data were obtained from the new generation of GOES satellites (GOES-16), the SIPAM S-band radar, two SMPS instruments sampling from 60 and $325 \mathrm{~m}$ height above ground, and the LAP 3000 radar wind profiler installed at the ATTO-Campina site. ATTO-Campina is a new site to complement ATTO measurements with cloud physics instruments, specifically designed for the study of aerosol-cloud-precipitation interactions. The Campina site is located about $4 \mathrm{~km}$ from the main tower in a small isolated clearing, characterized by relatively dry and sandy soils as well as the typical low Campina vegetation type (Junk et al., 2011). The small size of the trees allowed the installation of remote sensing instruments to measure cloud physics. All datasets used in this study were organized and compiled to produce 2 years of data with $10 \mathrm{~min}$ time resolution, from October 2017 to September 2020. Detailed descriptions of the individual datasets are presented below. 


\subsection{Scanning mobility particle sizers}

This study focuses on particle number size distribution measurements obtained from two scanning mobility particle sizers (SMPSs, TSI Inc., Shoreview, USA), each comprising a differential mobility analyzer (DMA) and condensation particle counter (CPC). Both SMPS systems were measuring in parallel at two different sampling heights at the ATTO site. One SMPS was sampling from the $60 \mathrm{~m}$ inlet of the triangular mast and the second from the $325 \mathrm{~m}$ inlet of the Tall Tower. Due to several instrument failures in the course of the long-term measurements, the DMA and CPC instruments were replaced as necessary. These replacements involved different DMA and CPC models: the measurements at the $60 \mathrm{~m}$ inlet involved the classifier models 3080 and 3082, the DMA model 3081, and the CPC model 3722 . The measurements at the $325 \mathrm{~m}$ inlet involved the classifier model 3082, the DMA model 3081, and the CPC models 3722 and 3750 (for details, see Andreae et al., 2015; Pöhlker et al., 2016). Both instruments are located in air-conditioned laboratory containers at the foot of the towers. Sample air was transported through stainless steel tubes (finetron tubes, Dockweiler AG, Neustadt-Glewe, Germany) and dried to a relative humidity (RH) below $40 \%$. At the $60 \mathrm{~m}$ inlet, an automatic regenerating silica gel adsorption aerosol dryer, as described in Tuch et al. (2009), was installed upstream of the instruments in 2014 and was replaced by a custom-built and automated condensation aerosol dryer in March 2020. At the $325 \mathrm{~m}$ inlet, an automated condensation dryer has been used since the beginning of measurements. Both SMPS instruments cover a particle size range from 10 to $400 \mathrm{~nm}$, and the sizing accuracy was frequently checked using monodisperse polystyrene latex particles. Data were acquired and exported with the Aerosol Instrument Manager Software (AIM, Version 9 and 10, TSI Inc., Shoreview, USA). The original temporal resolution was $5 \mathrm{~min}$ and was integrated to $10 \mathrm{~min}$ to maintain the same time resolution as the other data. The data were adjusted for standard temperature $(273.15 \mathrm{~K})$ and pressure $(1013.25 \mathrm{hPa})$. The theoretical losses due to the long inlets at 60 and $325 \mathrm{~m}$ were corrected based on a methodology using size-dependent correction factors, as described by von der Weiden et al. (2009).

For the purpose of our analysis, we divided the PSD, obtained by the SMPS over the range from 10 to $400 \mathrm{~nm}$, into the following three individual size classes: (a) ultrafine aerosol particles (UFPs) from 10 to $50 \mathrm{~nm}$, (b) Aitken mode particles from 50 to $100 \mathrm{~nm}$ and (c) accumulation mode particles from 100 to $400 \mathrm{~nm}$ (see also multimodal fitting in Pöhlker et al., 2016). In order to evaluate the particle characteristics along the classes, we computed the cross-correlation between the different particles sizes for the central Amazonian dry (June to October) and wet (December to April) seasons. Figure 1 shows how well the multimodal PSDs are described by the aforementioned modes by means of a crosscorrelation plot for the dry season. The accumulation mode
Table 1. Definitions, name abbreviations and symbols of the three aerosol particle size ranges used in this study.

\begin{tabular}{llr}
\hline Name of aerosol particle class & Concentration & $\begin{array}{r}\text { Diameter }(D) \\
\text { range }[\mathrm{nm}]\end{array}$ \\
\hline Ultrafine particles (UFP) & $N_{\mathrm{UFP}}$ & $10<D \leq 50$ \\
Aitken mode particles & $N_{\mathrm{AIT}}$ & $50<D \leq 100$ \\
Accumulation mode particles & $N_{\mathrm{ACC}}$ & $100<D \leq 400$ \\
\hline
\end{tabular}

particles and Aitken mode particles have a clearly defined separation at $100 \mathrm{~nm}$, mainly during the wet season, which is the location of the Hoppel minimum (Hoppel et al., 1996) as observed in central Amazonia by Pöhlker et al. (2016). However, the separation between Aitken mode particles and UFP is not clearly evident. The Aitken mode particles have a smaller cross-correlation between the particles, which can likely be explained by the fact that this range of particles is in the transition between the other two modes. Specifically, the Aitken mode particles appear to have sometimes nucleation mode particle properties and sometimes accumulation mode particles properties. Clearly, the UFP and accumulation mode particles are well cross-correlated between the different particle sizes; however, for the wet season this separation is not well defined. In the wet season there is an increase in cross-correlation from Aitken particles to UFP, but the cross-correlation inside the population of the UFP is smaller than during the dry season. The UFPs are in a size range where Aitken and nucleation particles modes overlap; therefore we adopted the ultrafine particle denomination for this size range, which was shown to be very sensitive and with a different behavior from the other particle classes, as will be shown in this study. Fan et al. (2018) used the same size range to show the effect of UFP in the strengthening of convective updrafts. Given the overlap between the nucleation and Aitken modes and the growth of particles from one mode into the other, the cut at $50 \mathrm{~nm}$ is somewhat arbitrary, but as will be shown below, it provides a practical basis for discussing the behavior of these particle classes in response to meteorological events and across diurnal and seasonal timescales. Table 1 summarizes the definitions, abbreviations and size ranges of aerosol particle classes used in this study.

\subsection{Geostationary Operational Environmental Satellite}

The Geostationary Operational Environmental Satellite (GOES) is the operational NOAA (National Oceanic and Atmospheric Administration) satellite covering South America. In 2016, NOAA launched the new generation of geostationary satellites, GOES-16, located at $75.2^{\circ} \mathrm{W}$. GOES-16 has a new set of instruments; in particular, used in this study are the Advanced Baseline Imager (ABI) and the Geostationary Lightning Mapper (GLM). The GOES-16 ABI sensor data employed are ABI channel $13(10.35 \mu \mathrm{m})$. ABI channel 13 

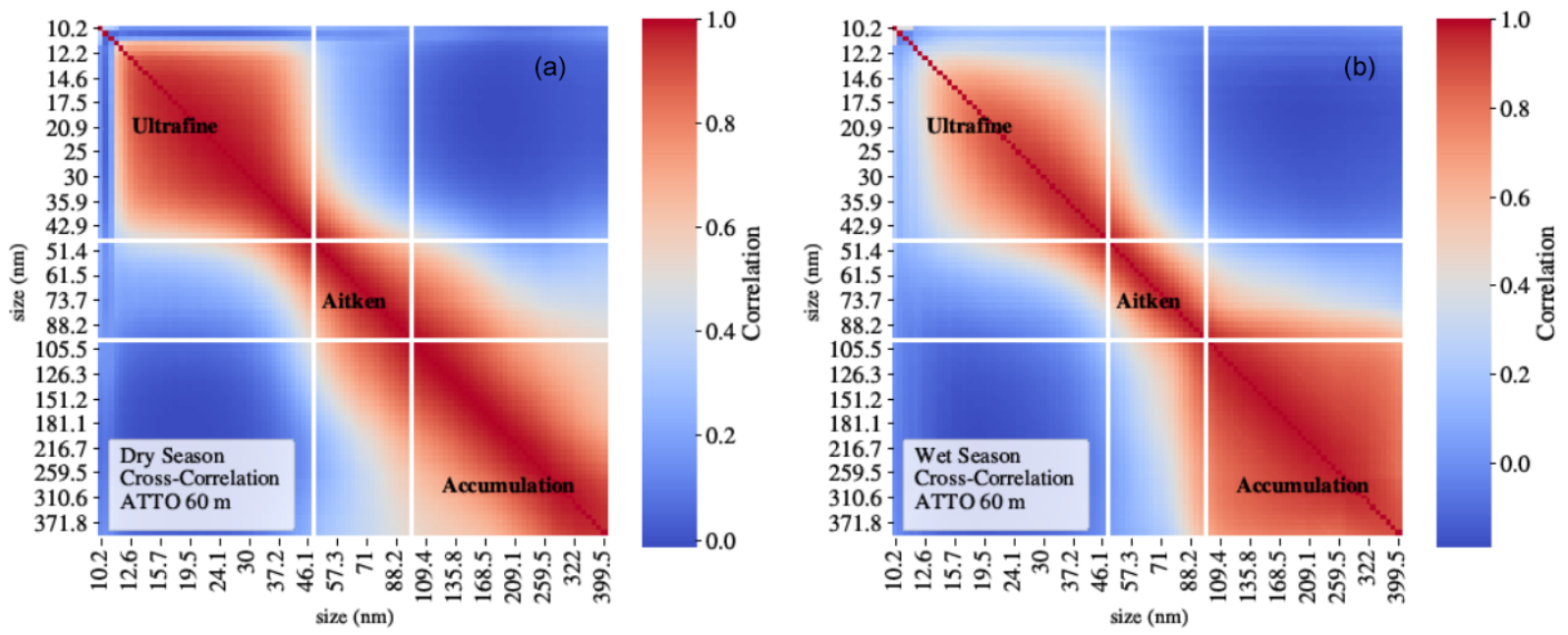

Figure 1. Particle number size distribution cross-correlation sampled at $60 \mathrm{~m}$ height at ATTO. (a) Dry season (June to October) and (b) wet season (December to April). The cross-correlation underlines the distinction into ultrafine, Aitken and accumulation modes.

has $2 \mathrm{~km}$, and the GLM has $8 \mathrm{~km}$ spatial resolution, both of them in their original satellite projection. Channel 13 is usually used to estimate the convective cloud depth, where lower brightness temperature $\left(T_{\mathrm{IR}}\right)$ relates to higher cloud tops simply because the temperature decreases with height in the troposphere (Adler and Mack, 1986). From ABI channel 13, three variables were selected, namely, the ATTO colocated $T_{\mathrm{IR}}$ as well as the frequency of occurrence of $T_{\mathrm{IR}}<284$ and $T_{\mathrm{IR}}<245 \mathrm{~K}$, in a grid of 5 by 5 pixels centered on ATTO. Clear-sky radiance in Amazonia is associated with the mixed layer brightness temperature due to the high amount of water vapor near the surface. Machado et al. (2002) used the $284 \mathrm{~K}$ threshold to estimate the total cloud cover. The threshold of $245 \mathrm{~K}$ is usually employed to describe clouds associated with convective events in tropical regions.

The lightning data were obtained from the GLM, which detects lightning from a $0.74 \mu \mathrm{m} \mathrm{CCD}$ array with a very high temporal resolution, so it can compare the energy peak at different times to define whether it is a lightning event or not (detailed description in Goodman et al., 2013). To obtain a better representation of lightning around ATTO, the GLM information was computed as the lightning density: the number of events every $10 \mathrm{~min}$ in an area of 5 by 5 GLM pixels, which corresponds to a description of lightning activity in a $25 \mathrm{~km}$ radius.

\subsection{S-band radar}

The SIPAM S-band radar is a weather radar, located in Manaus and operated by SIPAM - Sistema de Proteção da Amazônia. This S-band radar $(10 \mathrm{~cm}$ wavelength $-3.0 \mathrm{GHz})$ has a beam width of $1.8^{\circ}$ and a $240 \mathrm{~km}$ radius coverage. The radar run occurs every $12 \mathrm{~min}$, a volume scan strategy covering 17 elevations. The volume scan produces a 3-D description of the atmosphere. The following parameters were ob- tained from the 3-D field: the constant altitude plan position indicator (CAPPI) is the reflectivity (dBZ) field at a specific height; in this case we have used the CAPPI at $3 \mathrm{~km}$. There is a direct relationship between reflectivity and rainfall; the Marshall-Palmer relationship assumes an exponential dropsize distribution and defines rain rate $(R)$ as $Z=200 R^{1.6}$, where $Z$ is the reflectivity in $\left(\mathrm{mm}^{6} \mathrm{~m}^{-3}\right)$ and $R$ is in $\mathrm{mm} \mathrm{h}^{-1}$. The CAPPI $3 \mathrm{~km}$ is usually associated with the rain rate if rainfall evaporation below $3 \mathrm{~km}$ is neglected. The $3 \mathrm{~km}$ height is employed to be free of clutter and the Earth curvature effects in the $240 \mathrm{~km}$ radius. The echo top corresponds to the maximum height of cloud threshold of $20 \mathrm{dBZ}$ and can be considered as the height of the top of the rain rate associated with the reflectivities describe above. The $20 \mathrm{dBZ}$ echo top is approximately the height of the cloud top with rain drops corresponding approximately to the rain rate of $1 \mathrm{mmh}^{-1}$. The VIL is the vertically integrated liquid $\left(\mathrm{kg} \mathrm{m}^{-2}\right)$. VIL is obtained by the vertical integration of the reflectivity as described by Greene and Clark (1972).

\subsection{LAP3000}

The LAP3000 radar wind profiler (RWP) is a vertically pointing radar capable of measuring Doppler velocity spectra profiles under both clear-sky and precipitation conditions. It operates in the $1290 \mathrm{MHz}$ frequency range, with a $7.1^{\circ}$ beam width, and obtains the Doppler spectra based on oscillations of the refractive index of air in the case of clear sky or based on droplet relative motion in the case of precipitation. The instrument is set up to operate in three different modes, one optimized for clear sky and the other two for precipitation. The precipitation modes are obtained in a similar fashion as in Tridon et al. (2013), which aims to convert the RWP to an S-band-like profiler. A similar approach was already used in the Amazon during the 2-year deployment of the 
Atmospheric Radiation Measurement (ARM) Mobile Facility (AMF) during the GoAmazon2014/5 experiment (Martin et al., 2017, 2016; Giangrande et al., 2017). The present study only used data from one of the precipitation modes, which is able to sample between 1 and $15 \mathrm{~km}$ altitude with spatial and temporal resolutions of $210 \mathrm{~m}$ and $9.5 \mathrm{~s}$, respectively. The pulse repetition frequency (PRF) is set to $8300 \mathrm{~Hz}$, and the velocity range is between -20 and $+20 \mathrm{~m} \mathrm{~s}^{-1}$ with $0.1 \mathrm{~m} \mathrm{~s}^{-1}$ resolution. The spectra moments are integrated into 5 min intervals for the analysis of the up- and downdrafts.

This instrument was employed to compute the statistical profile of the vertical velocity inside convective clouds. The analysis of resultant vertical velocity obtained by the RWP at the ATTO-Campina site was done by computing the contoured frequency-by-altitude diagram, a tool normally used in radar data analysis (detailed description in Yuter and Houze, 1995). As this is a new instrument installed at ATTO site, the calculation was performed for only $54 \mathrm{~d}$ of measurements between 16 October and 8 December 2020. The vertical resolution of the contoured frequency-by-altitude diagram is set to $840 \mathrm{~m}$, while the vertical velocity resolution is $0.1 \mathrm{~m} \mathrm{~s}^{-1}$.

\section{Results}

This section explores how particle size distribution changes as a function of the main atmospheric cycles and cloud cover characteristics. The main atmospheric cycles in Amazonian are the seasonal and diurnal cycles. But the atmosphere also varies in the intradiurnal and interdiurnal frequencies. This section will also evaluate how the intradiurnal variability is associated with the PSD. Intradiurnal cloud variability is mainly forced by gravity waves, and this topic will be discussed in Sect. 3.7. The PSD associated with the cloud characteristics will be evaluated mainly by looking at the lightning density as a proxy of deep convection. This study also evaluates PSD as a function of cloud top height, rainfall, cloud-integrated liquid water and brightness temperature. These evaluations allow building a holistic view of how weather modifies the particle size distribution. One of the main topics covered in this study is the association between BL dynamics and new particle formation. One remarkable feature already observed in case studies is the increased concentration of UFP during deep convective events. Section 4 will discuss and evaluate the different possibilities and the associated processes.

\subsection{Seasonal cycle}

The seasonal cycle in the Amazonian region is very important to be studied because this region presents a very well-defined annual variation, with a dry season in the austral winter and a wet one in the austral summer. Moreover, the transition phases between wet to dry and dry to wet seasons present distinct behaviors of chemical and atmospheric prop- erties. The dry season has higher particle concentration and the most intense thunderstorms. In contrast, the wet season has higher precipitation accumulation but with lower rain rates and particle concentration. Machado et al. (2004) and Pöhlker et al. (2018) present a complete description of the seasonal variability. The total particle number concentration varies by about 1 order of magnitude between wet and dry seasons (Andreae et al., 2015; Andreae, 2009). Pöhlker et al. (2016) discuss the seasonal variation of cloud condensation nuclei $(\mathrm{CCN})$ in central Amazonia and conclude that the variability in the $\mathrm{CCN}$ concentrations is mostly driven by the aerosol particle number concentration and size distribution. Moran-Zuloaga et al. (2018) present multi-year accumulation and coarse-mode measurements at ATTO and discuss the large diversity of the aerosol sources. Varanda Rizzo et al. (2018) present a multi-year analysis of submicrometer particle size spectra at ATTO for the wet and dry season. Figure 2 clearly shows this high variability for all sizes, with a maximum number concentration at the end of the dry season, mainly in the range between 100 and $200 \mathrm{~nm}$.

In addition, Fig. 2 shows the seasonal evolution of the brightness temperature $\left(T_{\mathrm{IR}}\right)$ and the lightning density. The brightness temperature starts to increase from May to July, characterizing the decrease in cloud cover and the frequency of occurrence of convective clouds, followed by the increase in particle number concentration. High $T_{\mathrm{IR}}$ values $\left(T_{\mathrm{IR}}>284 \mathrm{~K}\right)$ are associated with low cloud cover or shallow convection, and cold $T_{\mathrm{IR}}\left(T_{\mathrm{IR}}<235 \mathrm{~K}\right)$ are associated with deep convection. April is the month with the coldest $T_{\mathrm{IR}}$ and the rainiest month, but the maximum lightning activity is in September when deep convective rainfall events become more frequent. The brightness temperature and PSD relationship is straightforward, where higher $T_{\mathrm{IR}}$ is associated with reduced rain and higher particle concentration during the dry season and lower particle concentration during the wet season when $T_{\mathrm{IR}}$ is colder, representing higher (colder) cloud tops. However, the lightning activity shows the sharpest increase at the time when the aerosols have the maximum concentration (August). The transition between dry to wet season is the time when clouds are deeper and more intense, consequently having more electrification activity.

The seasonal cycle of the particle number concentration at different altitudes shows interesting features. From the wet to the dry season, the $N_{\text {UFP }}$ is nearly constant at $60 \mathrm{~m}$ but increases at $325 \mathrm{~m}$ (Fig. 3a). The absolute value of the difference between the concentration at 60 and $325 \mathrm{~m}$ is small and could depend on the correction employed for losses in the long inlet tubing at $325 \mathrm{~m}$. The $N_{\mathrm{ACC}}$ (Fig. $3 \mathrm{~b}$ ) has the same phase and nearly the same average concentration at 60 and $325 \mathrm{~m} \mathrm{(511} \mathrm{and} 556 \mathrm{~cm}^{-3}$, respectively). 

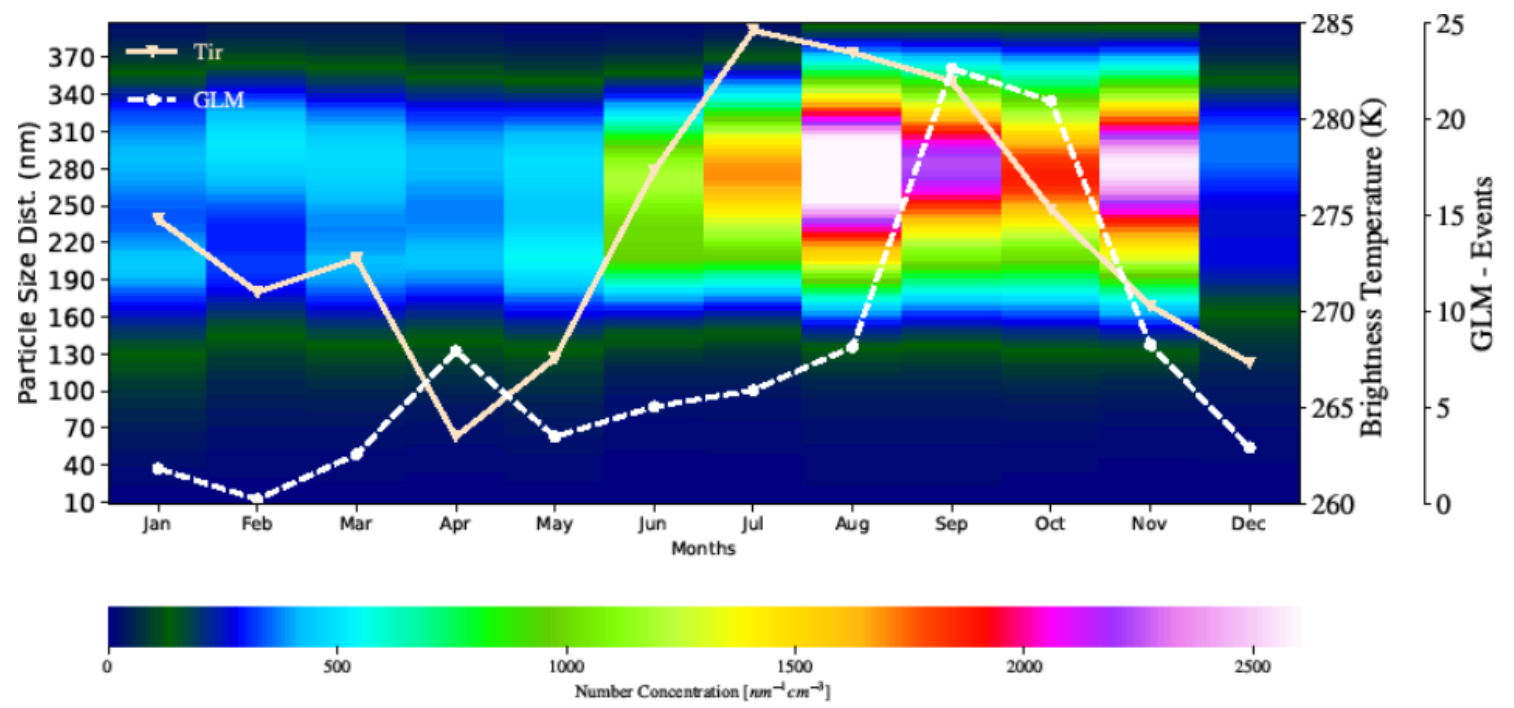

Figure 2. Seasonality of particle size distributions at ATTO (60 m sampling height), brightness temperature $\left(T_{\mathrm{IR}}\right)$ and lightning density (number of lightnings per $5 \mathrm{~min}$ time bins in area of $50 \times 50 \mathrm{~km}^{2}$ around ATTO). All values are shown as monthly means. Average time frame for all parameters ranges from October 2018 to September 2020.
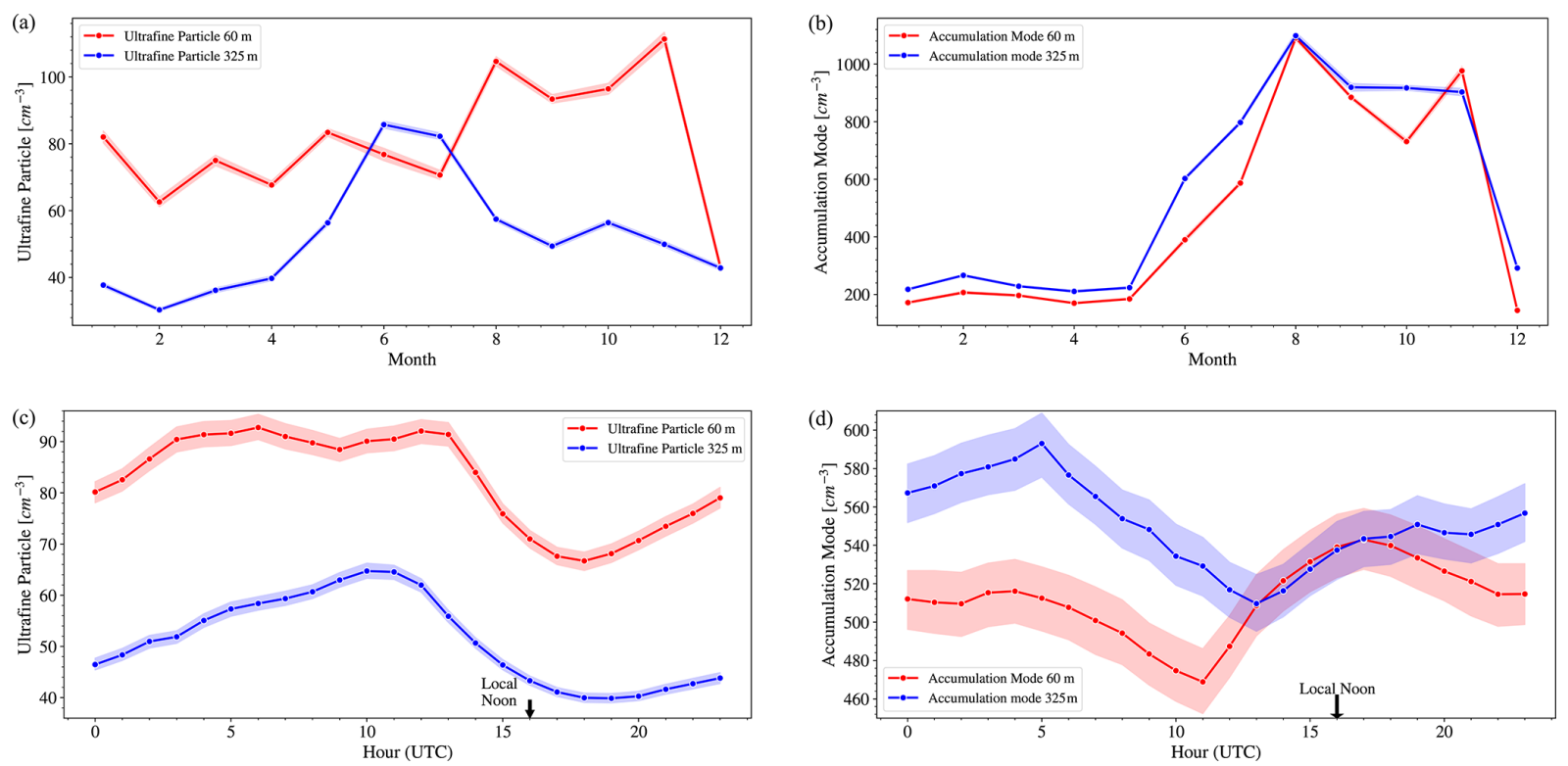

Figure 3. Seasonal and diurnal variation of the number concentration of ultrafine and accumulation mode particles: (a) monthly average of the ultrafine particles at 60 and $325 \mathrm{~m}$, (b) monthly average of the accumulation mode at 60 and $325 \mathrm{~m}$, (c) hourly average of ultrafine particles at 60 and $325 \mathrm{~m}$, (d) hourly average of accumulation mode at 60 and $325 \mathrm{~m}$. The shaded area corresponds to a confidence interval of $95 \%$. Time is UTC; LST is UTC $-4 \mathrm{~h}$.

\subsection{Diurnal cycle}

Clouds in Amazonia have a typical diurnal cycle during both the wet and dry seasons (Machado et al., 2004). The cloud diurnal cycle and BL processes modify the PSD (Betts et al., 2002; Saturno et al., 2018). Figure 4 shows the diurnal cycle of the PSD for the dry and wet seasons. Although the dry season has a much larger aerosol concentration than the wet season - on average about a factor of 5 higher (Moran-Zuloaga et al., 2018) - the diurnal cycle for the wet and dry seasons commonly shows a minimum in $N_{\mathrm{ACC}}$ and $N_{\mathrm{AIT}}$ at the end of the night and during early morning (i.e., 04:00 to 08:00 local time (LST), which is UTC $-4 \mathrm{~h}$ ). It affects mainly the smaller sizes in the accumulation mode. This minimum during late night and early morning is followed by an increase in $N_{\mathrm{ACC}}$ up to the time when $T_{\mathrm{IR}}$ starts do decrease and lightning density increases in the afternoon. This is the time when 

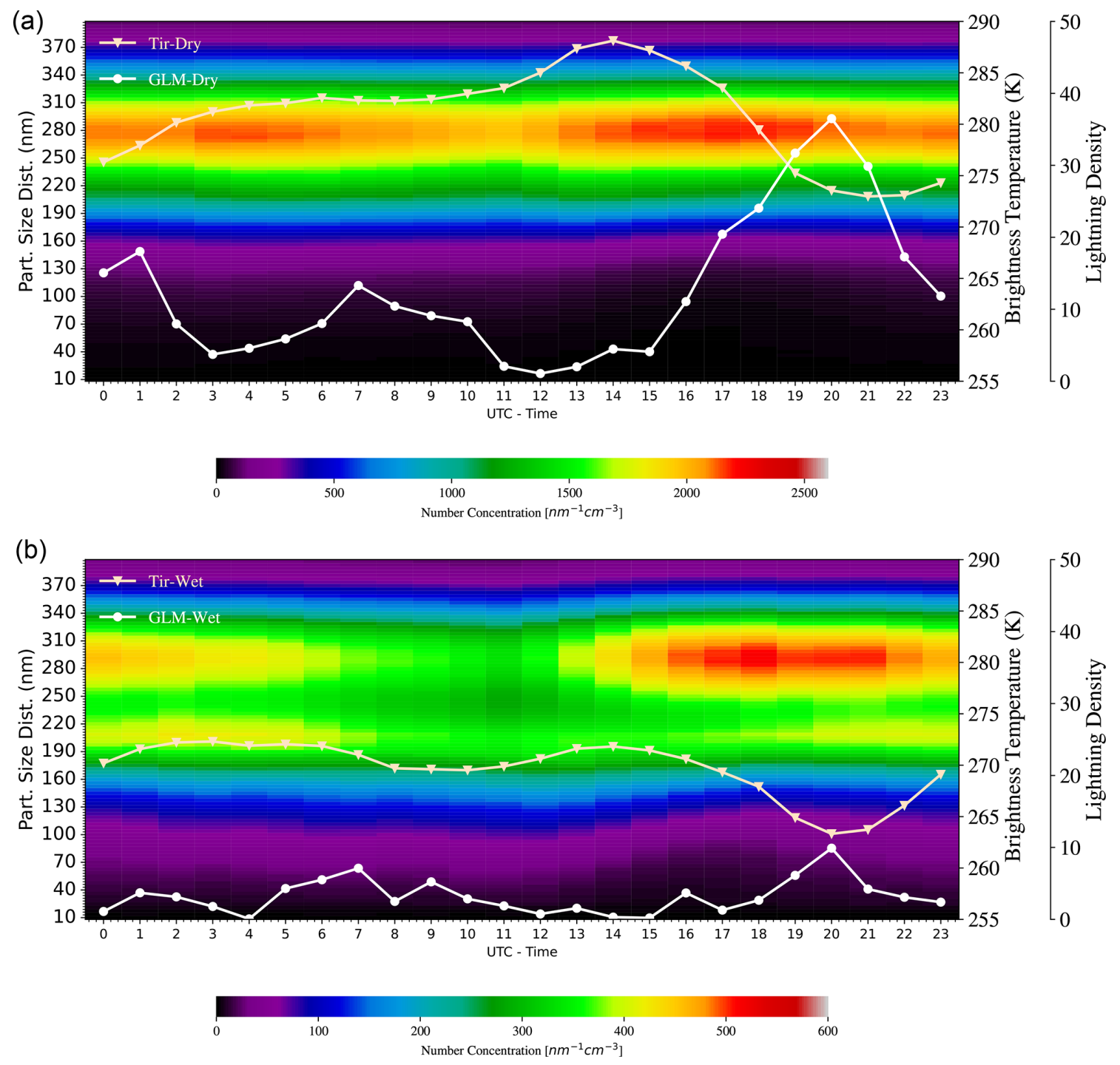

Figure 4. Diurnal cycle of the particle size distribution at ATTO (60 m sampling height) during the dry season (June-October) (a) and wet season (December-April) (b). The monthly mean brightness temperature and lightning density (number of lightning events in 5 min in $50 \times 50 \mathrm{~km}^{2}$ ) are plotted as white and gray lines with solid lines. Time is UTC; LST is UTC $-4 \mathrm{~h}$.

the maximum in $N_{\mathrm{ACC}}$ is observed. Moran-Zuloaga et al. (2018) show, for the wet season, that episodic intrusions of African long-range transport of aerosols strongly increase the coarse mode in the early afternoon, when air is mixed down into the PBL from the dust-laden layer aloft.

The increase in the number concentration between morning and noon is coincident with the time when surface sensible heat flux becomes positive, the nocturnal BL is eroded, and the convective BL is rapidly built (Stull, 1988; Angevine et al., 2020; Fisch et al., 2004). At this time, the BL evolves from the stable stage (nocturnal BL) to the convective BL (mixed layer). Following Stull (1988) classification of the stages of BL evolution, Henkes et al. (2021) show in detail the BL height evolution and surface fluxes for these stages of the development of the convective BL in central Amazonian region during the dry season. The growing stage begins at sunrise and is determined by the time when the surface heat flux passes above zero and the turbulent kinetic energy promotes rapid growth of the convective BL. At this time, the BL could exports particles to the free troposphere (the Earth's atmosphere above the PBL) or/and mix from free atmosphere into the lower BL; later in the afternoon, they are removed by precipitation scavenging. The differences between wet and dry season convective processes are very clear; from the meteorological point of view, the dry season has higher lightning activity and warmer $T_{\mathrm{IR}}$, and vice versa in the wet season.

To observe the diurnal modulation of PSD in more detail, the daily evolution and relative variation (variation around the mean value) were computed for $N_{\mathrm{UFP}}, N_{\mathrm{AIT}}$ and $N_{\mathrm{ACC}}$ 

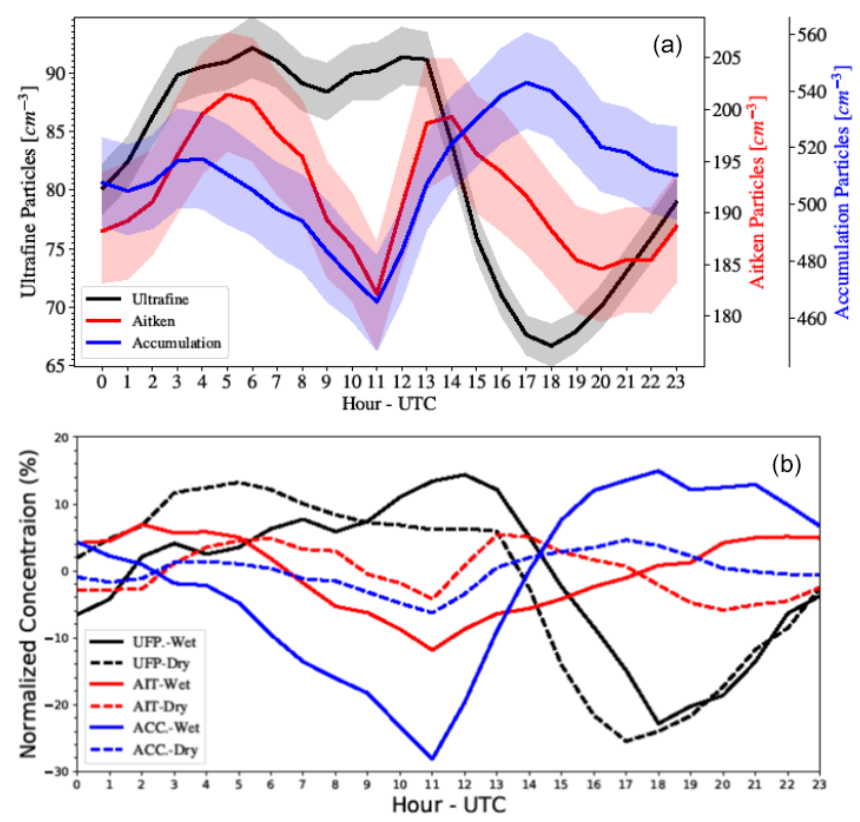

Figure 5. (a) Diurnal cycle of the ultrafine (black), Aitken (red) and accumulation mode particles (blue) at $60 \mathrm{~m}$ sampling height. The shaded area corresponds to a confidence interval of $95 \%$. (b) Mean deviation of the diurnal cycle of ultrafine, Aitken and accumulation mode particles during dry (dashed line) and wet (solid line) seasons. Time is UTC; LST is UTC $-4 \mathrm{~h}$.

(Fig. 5). $N_{\mathrm{ACC}}$ and $N_{\mathrm{AIT}}$ decrease during the night; the nocturnal BL height is normally above $60 \mathrm{~m}$ (Carneiro and Fisch, 2020), so this decrease is likely related to the interaction between the surface and the BL. Henkes et al. (2021) discuss the shallow and deep convective events. For both types of events, the nocturnal boundary layer has nearly zero and sometimes negative latent and sensible surface flux, as well as nearly zero turbulence kinetic energy, consequently no effective mechanism to support exchange between BL and free atmosphere. Therefore, this behavior can be attributed to dry deposition to the vegetation and ground surfaces, as there are no other sinks because the exchange across the top of the $\mathrm{BL}$ is very small due to the large stability in this layer. Fog, usual in the wet season early morning (Anber et al., 2015), could also contribute to this behavior, though the nighttime decrease is a systematic behavior during the dry and wet season. Whereas $N_{\mathrm{ACC}}$ and $N_{\mathrm{AIT}}$ decrease during the night, the UFP number concentration remains nearly constant (dry season) or even increases in the wet season. This topic will be specifically discussed in the next section.

This behavior changes completely at sunrise, when accumulation and Aitken particles start to increase and $N_{\text {UFP }}$ decreases, with the typical behavior of a particle size growth process, from ultrafine to Aitken and eventually to accumulation mode sizes (note that $N_{\text {AIT }}$ starts to decrease at approximately 13:00 UTC (09:00 LST)). As concentration also increases, there is also a contribution from the vertical trans- port to the BL. This process is observed up to the middle or end of the afternoon, when the concentration of accumulation particles begins to decrease and ultrafine particles increase in phase with the increase in the afternoon convective processes. Figure 5b shows the proportional diurnal variation, relative to the overall mean value, for the dry and wet seasons. It is interesting to note that despite their lower concentration relative to the accumulation mode particles, the UFPs have the largest relative diurnal variation in both sea-

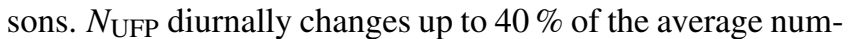
ber concentration. $N_{\mathrm{ACC}}$, as already shown, varies in absolute number much more, but as the number concentration is very high, mainly in the dry season, the relative variation is very small. An exception occurs during the wet season, when $N_{\text {ACC }}$ is reduced by up to $30 \%$ during the night. Thus, despite the much larger concentration in the dry season, the relative daily variability is larger during the wet season. This result indicates that the diurnal cycle not only mainly controls $N_{\text {UFP }}$, but also provides a modest decrease in the concentration of the larger modes during the night and shows a growth process from morning to the time that rainfall starts.

The diurnal cycle of $N_{\text {UFP }}$ (see Fig. 3c) has an oscillation in phase among the two heights, with minimal values in the early afternoon. However, the diurnal cycle of $N_{\mathrm{ACC}}$ (see Fig. 3d) shows the number concentration at $60 \mathrm{~m}$ having its minimal value earlier than at $325 \mathrm{~m}$ and a similar concentration in the early morning when the convective BL is developing. This feature shows the importance of the BL evolution in shaping the particle size distribution.

\subsection{Lightning density and particle size distributions}

This section explores the relationship between lightning events and PSD. To understand how the PSD changes as function of the weather events, we evaluate the relationship between thunderstorms (i.e., storms producing lightning) and the evolution of $N_{\mathrm{UFP}}, N_{\mathrm{AIT}}$ and $N_{\mathrm{ACC}}$ from $400 \mathrm{~min}$ before to $400 \mathrm{~min}$ after the maximum lightning activity.

To describe the evolution of ultrafine, Aitken and accumulation mode particles, composite analyses were produced based on the maximum lightning density activity. Composite analyses are useful tools to form physical hypotheses on the associations between environmental variables that occur over time (Boschat et al., 2016). Composite analysis is a useful technique to determine basic characteristics of a particular phenomenon. This type of analysis involves collecting large numbers of standardized cases of a given phenomenon and compositing them together as a collection. It involves computing the composite mean and statistical significance of the selected pattern, in this case the lightning occurrence and other cloud characteristics.

The composite depends on the specified threshold to create a collection of cases. For lightning, the threshold was computed as percentiles of the lightning density distribution. This procedure allows comparing different thunderstorm in- 
tensities and their effect on PSD, as well as the effect of the other parameters describing cloud activity, such as cloud top height, rainfall and cloud liquid water. In order to have a comparable selection of lightning intensity and cloud properties, the lightning density selected was defined as a function of the percentile values of $25 \%, 45 \%, 65 \%, 85 \%$ and $95 \%$; these percentiles correspond to lightning density events of 2, 30, 137, 494 and 1192 (number of lightning events in $10 \mathrm{~min}$ in an area of 5 by 5 pixels centered at ATTO), respectively. The composites were produced by selecting the particle number concentration $400 \mathrm{~min}$ before and after the maximum lightning density for the different values of the selected percentiles. Figure 6 shows the typical evolution of $N_{\text {UFP }}, N_{\text {AIT }}$ and $N_{\text {ACC }}$ as a function of the maximum lightning density for different percentiles. Figure $6 \mathrm{~b}$ also shows the composite of the lightning density for the different percentiles. The number of cases in each composite depends on the percentile and ranges from 2520 for $25 \%$ to 159 cases for $95 \%$. Statistical significance was evaluated using Student's $t$ test, and there is a significant difference $(>99 \%)$ between the different modes and percentiles.

At approximately $100 \mathrm{~min}$ before the maximum lightning density, for any lightning intensity, $N_{\text {UFP }}$ particles increase in concentration, reaching maximum values of nearly double the initial concentration $200 \mathrm{~min}$ later. The difference in $N_{\text {UFP }}$ increases exponentially with the lightning density percentiles; i.e., the thunderstorm intensity controls the rate of change of the ultrafine number concentration. Deierling and Petersen (2008) found a high correlation between volume updraft and total lightning. Jadhav et al. (1996) showed an increase in ozone $\left(\mathrm{O}_{3}\right)$ and nitrogen dioxide $\left(\mathrm{NO}_{2}\right)$ column densities during thunderstorm events. Oxidation products of volatile organic compounds form secondary organic aerosol (SOA) to create new particles. Martin et al. (2010) discuss the mechanisms in the production of SOA in Amazonian forests and highlight the importance of nitrogen oxides and ozone in the oxidation processes and new particle formation. The increase in volume updraft also increases air mass flux exchange in mesoscale and consequently more frequent updrafts and downdrafts. Section 3.7 discusses these successive pulses of vertical movements forced by gravity waves. This cloud variability increases the frequency of downward transport and, consequently, the advection of ultrafine particles as suggested by Wang et al. (2016) and Andreae et al. (2018). In contrast, $N_{\mathrm{AIT}}$ and $N_{\mathrm{ACC}}$ decrease, reaching their minimum at nearly the same time as the maximum lightning activity. The main reason for this change could be an exchange of PBL air with air from the free troposphere, which is higher in $N_{\text {UFP }}$ and depleted in $N_{\mathrm{ACC}}$, or it could be due to the scavenging by the intense rainfall (more efficient for larger particles). These processes will be discussed in Sect. 4.

The reason for this increase in concentration of the UFP cannot be answered with the experimental design of this study. Still we can hypothesize that the reason is related to the UFP being brought down by the convective cloud down- drafts. The layer of large concentration of UFP in the upper troposphere is above $10 \mathrm{~km}$, but UFP, in lower concentration, is also found below this layer, where it is more reasonable to find downdrafts in convective clouds. Considering the time interval between the onset of the lightning activity and the maximum UFP at the surface $(60 \mathrm{~m})$ is around $100 \mathrm{~min}$ and the UFP is advected from $8 \mathrm{~km}$ to the surface, the mean downdraft velocity would be $1.3 \mathrm{~m} \mathrm{~s}^{-1}$. Schiro and Neelin (2018) show mean vertical velocity profiles for organized and isolated convective cells in the central Amazonian region, with the downdraft velocities from the surface up to $10 \mathrm{~km}$ being between 1 and $2 \mathrm{~m} \mathrm{~s}^{-1}$. This estimation could agree with the results from Wang et al. (2016) and Andreae et al. (2018), suggesting that the source of these UFP particles observed at the surface is in the upper troposphere. However, as already mentioned, downdraft is mainly concentrated in the middle troposphere; we will show in Sect. 4 that the Amazonian downdrafts are well below this upper tropospheric $(10-14 \mathrm{~km})$ layer, a source of ultrafine particles. A further possibility that needs to be considered is the production of UFP by the lightning discharges themselves, as has been demonstrated for a site in China by Wang et al. (2021)

\subsection{Relationship between lightning activity and aerosol background}

As already mentioned, the changes in $N_{\mathrm{AIT}}$ and $N_{\mathrm{ACC}}$ happen in an opposite direction to $N_{\mathrm{UFP}}$; these particles are removed, and specifically, $N_{\mathrm{ACC}}$ also starts to decrease $100 \mathrm{~min}$ before the maximum of lightning density (the same time when $N_{\text {UFP }}$ starts to increase). This observation indicates that the rainfall begins at approximately this time and intensifies up to the time of maximum lightning density, 100 min later. Interestingly, Fig. 6 shows that even before the onset of scavenging (i.e., more than $100 \mathrm{~min}$ prior to the lightning density peak), a higher density of lightning is associated with a higher accumulation number concentration. Higher lightning activity appears to be associated with a higher aerosol background condition. The aerosol concentration earlier than $100 \mathrm{~min}$ before the maximum lightning event is $30 \%$ higher at the 95 th percentile value than that at the 25 th percentile. Nonetheless, when approaching the time of maximum lightning activity and even later, the differences in $N_{\mathrm{ACC}}$ at the different lightning intensities become equal.

To understand this relationship of higher lightning activity at the time of higher aerosol background, a box-and-whisker diagram was computed relating lightning density and $N_{\mathrm{ACC}}$, 150 min before the maximum lightning event (Fig. 7). This time interval of $150 \mathrm{~min}$ before the intense weather event is an average time to detect the aerosol concentration before it is modified by the rain event. This figure highlights the positive correlation between the concentration of accumulation mode particles several hours before the maximum lightning activity and the increase in the frequency of the lightning events. During these periods of high-activity convective 

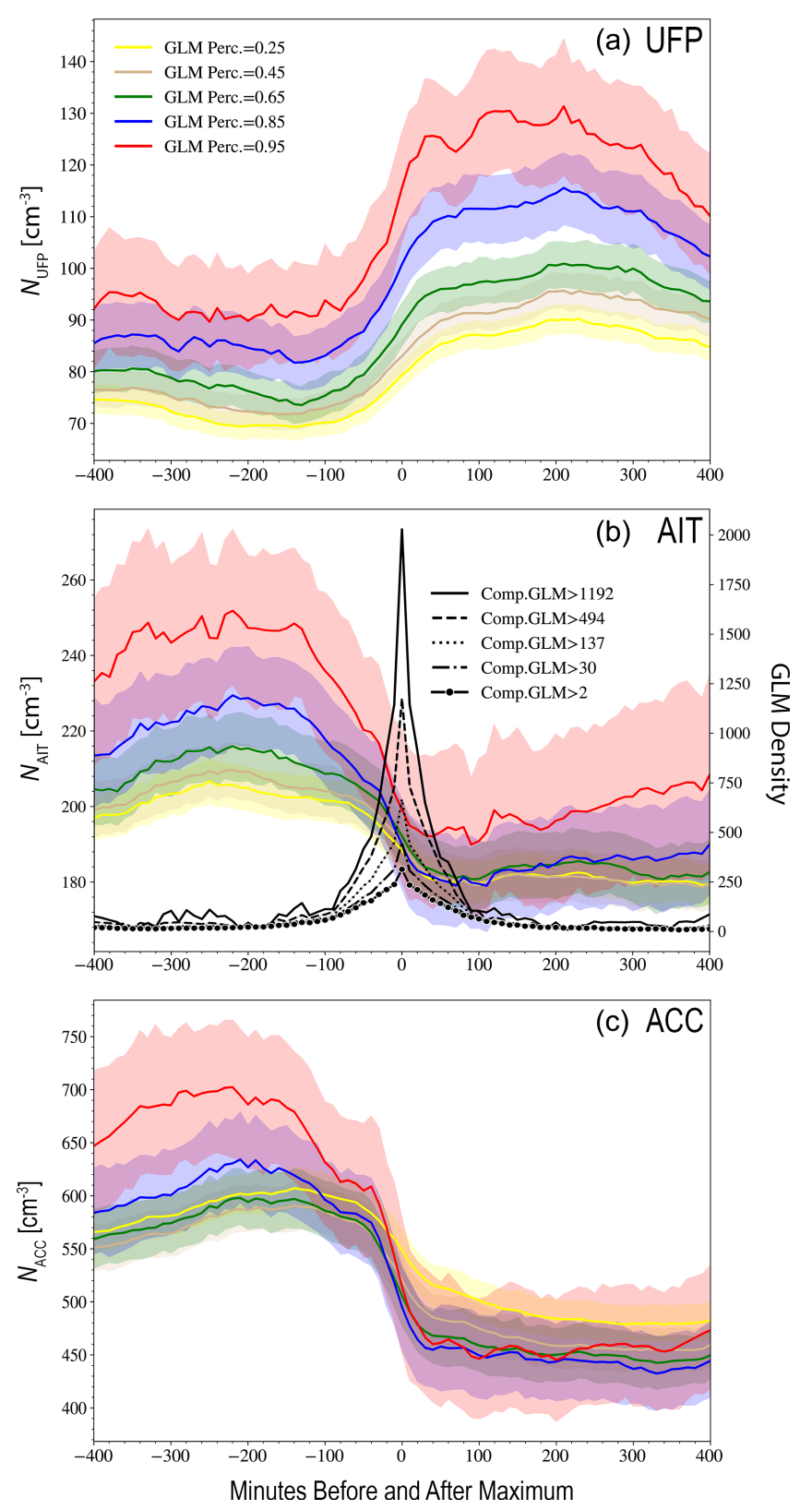

Figure 6. (a) Composite $N_{\mathrm{UFP}}$ as a function of the maximum lightning density events for different lightning density percentiles. (b) Composite $N_{\mathrm{AIT}}$ as function of the maximum lightning density events for different lightning density percentiles. The composite lightning frequency is shown for each percentile from continuous to dashed lines. (c) Composite $N_{\mathrm{ACC}}$ as function of the maximum lightning density events for different lightning density percentiles (60 m sampling height). The shaded area corresponds to confidence intervals of $95 \%$. events, with intense turbulence and well-developed convective BL, the PBL is thoroughly mixed. The time interval considered could be related to the time needed to clean up all the atmosphere by rainfall. This behavior could also explain the time interval between the beginning of the increase of ultrafine particles and the maximum lightning activity.

The relationship between high aerosol background and lightning activity is not clearly observed for all months of the year, although a trend of higher intensity lightning events related to high $N_{\mathrm{ACC}}$ is easily observed. Applying a Student $t$ statistical test we can reject the null hypothesis for specific classes, indicating that there is a significant difference (>95\%) between the means of the classes with lightning density smaller and larger than 400 lightning events. During the period from April to August, this relationship is not clearly observed. However, when we look at the less polluted months from December to February (Fig. 7b), this trend is clearer but less significant because the number of lightning events is smaller during this season. The reason cannot be answered with the present dataset, but the effect is better represented in this period than in a highly polluted situation. The sensitivity for invigoration should be higher at low aerosol loadings and become saturated at higher loadings (Rosenfeld et al., 2008). During May and April, the cleanest months (Pöhlker et al., 2018), this relationship is also observed but less pronounced than for the period from December to February. One possible explanation is the very low aerosol particle concentration that reduces the total number of $\mathrm{CCN}$.

Lightning acting to help increase the concentration of UFPs, which hours later grow to accumulation particles and in turn favor more lightning activity, is likely related to the convective invigoration processes (Rosenfeld et al., 2008). This is an interesting behavior, but as we will show, convection is mainly controlled by convective activity, which is strongly related to gravity waves and not to aerosol loading.

\subsection{Cloud characteristics and particle size distributions}

The same kinds of composite figures were prepared to analyze the effect of the rain rate (reflectivity at $3 \mathrm{~km}$ ), cloud top height, cloud liquid water content and brightness temperature on the PSD. In an effort to combine the different composites in the same figure, the deviations of the means were computed because the absolute magnitudes are different between these weather parameters. The composites are presented only for the maximum event defined by the threshold percentile value of $65 \%$. Different from the other variables, brightness temperature is a continuous value from clear sky to deep convective clouds. Therefore, a selection of the percentile value of $65 \%$ would be associated with many thousands of values, in contrast to rainfall/lightning events, where the data are only reported for rainfall or thunderstorm (lightning case) events. Therefore the percentiles for $T_{\mathrm{IR}}$ were defined only for values smaller than $245 \mathrm{~K}$, normally classified 

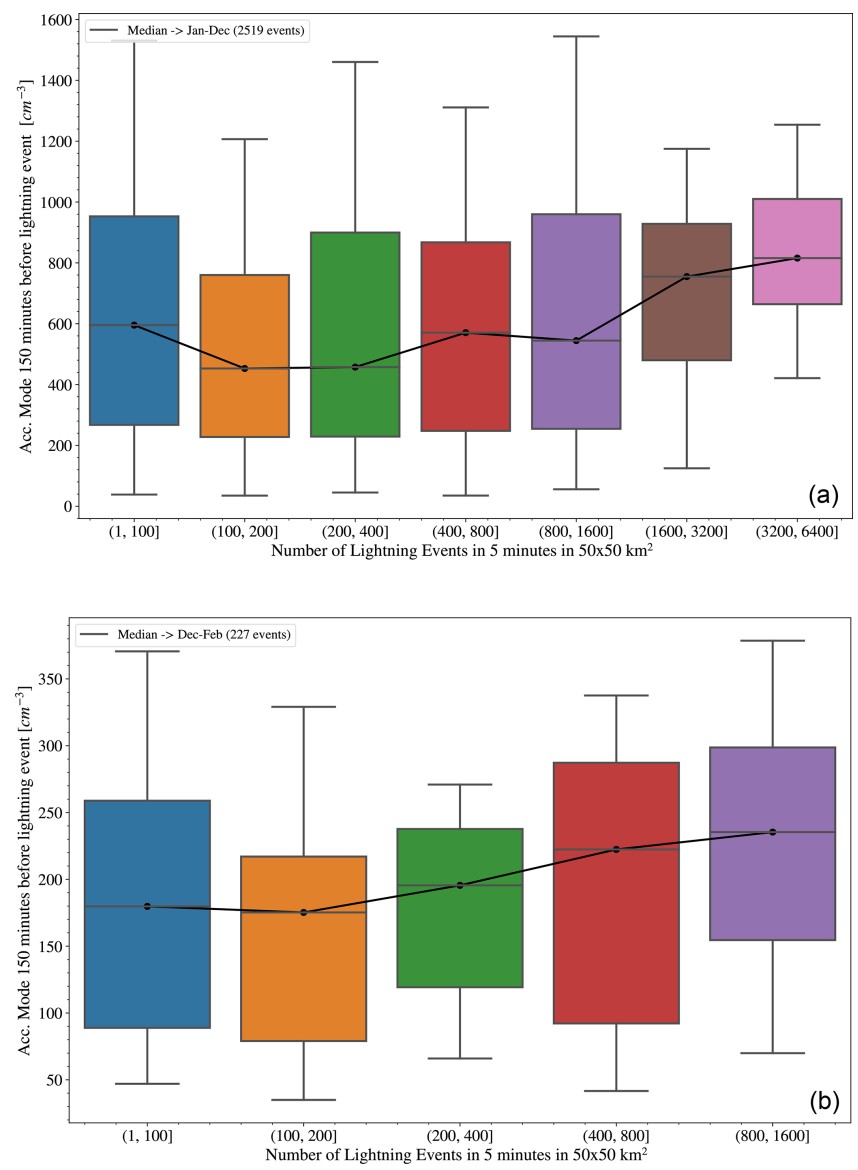

Figure 7. (a) Whisker diagram between lightning density classes and accumulation particle mode number concentration $(60 \mathrm{~m}$ sampling height), $150 \mathrm{~min}$ before the maximum lightning density for the two analyzed years. (b) The same as (a) but for December to February.

as the clouds associated with convective events (Machado and Rossow, 1993).

Figure 8 presents the evolution of $N_{\mathrm{UFP}}, N_{\mathrm{AIT}}$ and $N_{\mathrm{ACC}}$ from $400 \mathrm{~min}$ before to $400 \mathrm{~min}$ after the maximum of $T_{\mathrm{IR}}$, vertically integrated liquid water (VIL), the $20 \mathrm{dBZ}$ cloud top height (echo top), reflectivity at $3 \mathrm{~km}$ (rainfall) and lightning density, respectively, for wet and dry seasons. The results were split into dry and wet seasons to highlight the different behaviors. The effect on the evolution of particles is similar to the scenario shown for lightning, with a similar phase but with different amplitudes. The larger the amplitude, the more important is the effect of a specific meteorological variable in the modification of aerosol concentration. During the wet season, one can note changes around the mean value on the order of $25 \mathrm{~cm}^{-3}$ for the number concentrations from all variables, with the exception of lightning density, which produces larger variations of approximately $40 \mathrm{~cm}^{-3}$ in $N_{\mathrm{UFP}}$, $N_{\mathrm{AIT}}$ and $N_{\mathrm{ACC}}$. Thunderstorms that produce lightning are more intense than ordinary storms, and the stronger convective updrafts and downdrafts could explain this behavior.

The same feature is not observed for the dry season; lightning events are tied to similar or even smaller particle number concentration changes than the other variables. There are some possible reasons for this behavior, such as the large area of 5 by 5 pixels where lightning density is observed and the more localized convective cells during the dry season (Machado et al., 2018). This effect could likely minimize the variation of the number concentration at ATTO for smaller systems in the searched region that are farther from ATTO. One interesting point is the similar effect exhibited by the cloud liquid water, cloud top height (Tir) and rainfall on the evolution of the particle number concentration. These variables are well correlated, but the general effect on particles appears to be mainly related to the rainfall processes and associated updrafts and downdrafts. Recall that GLM captures only lightning that is more intense and closer to the cloud top; therefore, the population of rainfall clouds could also be associated with less intense and shallower lightning events. A second aspect observed in Fig. 8 is the different amplitudes of the rainfall effect on the particle number concentration between the wet and dry seasons. For $N_{\mathrm{ACC}}$, for instance, echo top changes imply values of approximately $47 \mathrm{~cm}^{-3}$ in the wet season versus $156 \mathrm{~cm}^{-3}$ in the dry season.

We concluded that convective events have a typical behavior, increasing $N_{\mathrm{UFP}}$ and reducing $N_{\mathrm{AIT}}$ and $N_{\mathrm{ACC}}$. However, this PSD modulation by weather events depends on the intensity of the convective event and has different sensitivities during the dry and wet seasons.

\subsection{The rate of change of PSD at 60 and $325 \mathrm{~m}$}

The preceding sections discussed how the concentrations of different particle modes evolve during convective events and how convective events are modulated by particle size concentrations. One way to evaluate in more detail how weather events modify the PSD is looking at the rate of change of the number concentrations of a specific mode as a function of lightning, at two different heights of 60 and $325 \mathrm{~m}$. The rate of change in the particle number concentrations $\left(N_{\mathrm{a}}\right)$ at two different heights gives an idea of how the flux of particles is being modified at a given instant during the occurrence of a lightning event. For the purpose of evaluating this rate of change of a specific mode in response to weather events, we select the composite of the lightning density and compute the rates of change of the number concentrations. This rate is computed as $\frac{\mathrm{dNa}}{\mathrm{d} t}$ in units of $\mathrm{cm}^{-3} \mathrm{~h}^{-1}$. Figure 9 presents the rate of change of particles in the wet and dry seasons for the lightning density composite.

Some noteworthy features can be observed in Fig. 9. First, UFP concentration changes have nearly the same phase in the wet and dry seasons; they are mainly negative between -400 and $-200 \mathrm{~min}$ and between +200 and $+400 \mathrm{~min}$ and positive between -200 and $+200 \mathrm{~min}$. The rate of change in the 
Wet Season
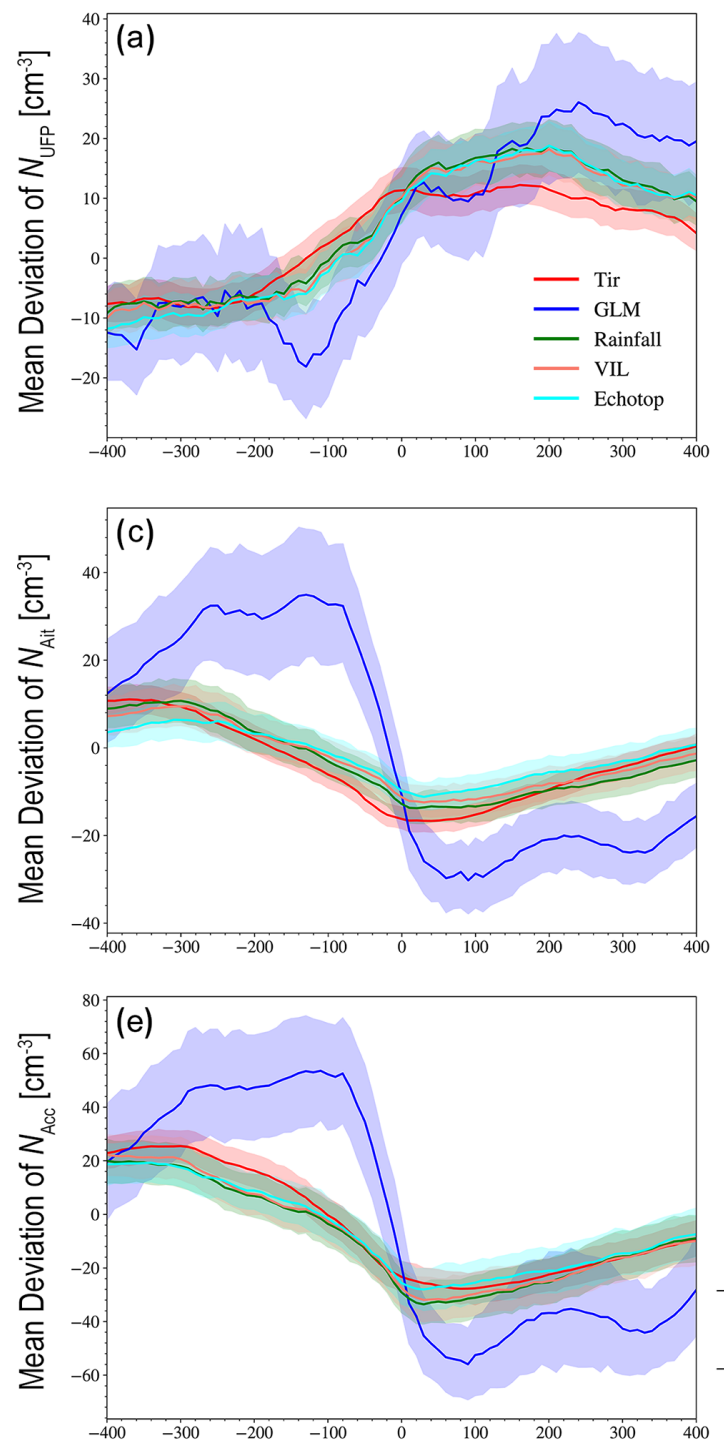

Minutes Before \& After Maximum (Minimum)
Dry Season
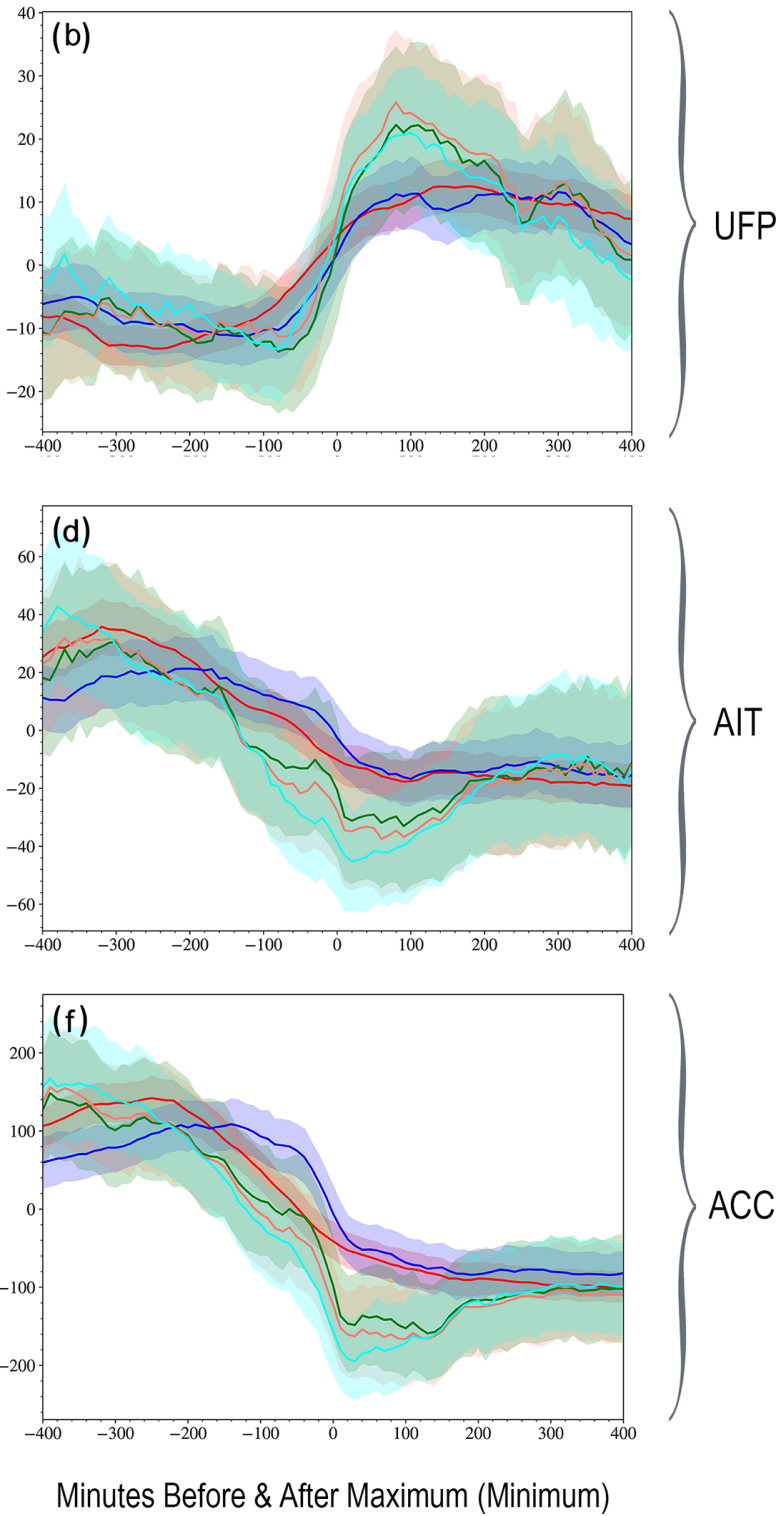

Figure 8. Composite reflectivity, vertically integrated liquid water (VIL), $20 \mathrm{dBZ}$ echo top, brightness temperature and lightning density for the percentile value of $65 \%$ for (a) $N_{\mathrm{UFP}}$ during the wet season, (b) $N_{\mathrm{UFP}}$ during the dry season, (c) $N_{\text {AIT }}$ for the wet season, (d) $N_{\text {AIT }}$ for the dry season, (e) $N_{\mathrm{ACC}}$ for the wet season and (f) $N_{\mathrm{ACC}}$ for the dry season (60 m sampling height). The shaded area corresponds to the $95 \%$ confidence interval.

wet season is larger and more than twice that of the dry season value at the time of maximum lightning density (minute zero). The rate of change at $60 \mathrm{~m}$ is higher than that at $325 \mathrm{~m}$. The ultrafine number concentration increases/decreases in $1 \mathrm{~h}$ nearly 4 times more at $60 \mathrm{~m}$ than at $325 \mathrm{~m}$. This observation indicates that the surface could also contribute as a source of UFP, increasing the UFP divergence flux in the BL. Even if the correction for the long inlet at $325 \mathrm{~m}$ is not sufficiently accurate to correct fully the losses of the concentration of small particles, this derivative does not depend on the absolute value. It, therefore, confirms the different behav- ior between 60 and $325 \mathrm{~m}$. For $N_{\mathrm{AIT}}$ and $N_{\mathrm{ACC}}$, in general, between -100 and +100 min there is a decrease in concentration and nearly no change during this period, except for $N_{\text {ACC }}$ later than +100 min, which shows a trend of increased concentration. For the accumulation mode particles, the rates of change of the number concentrations at 325 and $60 \mathrm{~m}$ have nearly the same magnitude. However, this effect is slightly larger during the dry season at $325 \mathrm{~m}$ and during the wet season at $60 \mathrm{~m}$.

The rate of change also decreases with height. It is possible that when the convective BL is being built, UFPs are 

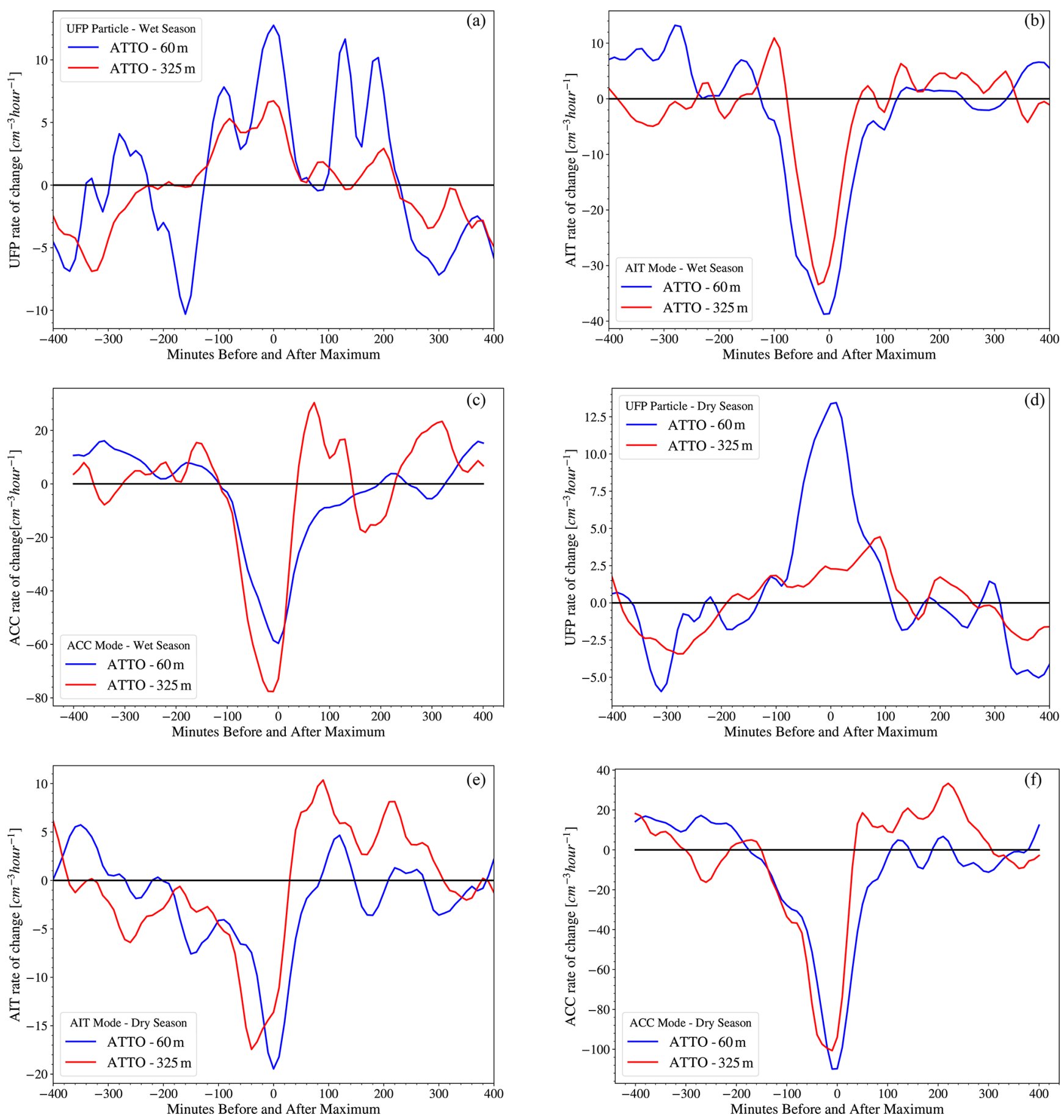

Figure 9. Rate of change in number concentrations from 400 min before to 400 min after the maximum lightning density ( 0.65 quartile) for (a) $N_{\mathrm{UFP}}$ at 60 and $325 \mathrm{~m}$ during the wet season, (b) $N_{\mathrm{AIT}}$ at 60 and $325 \mathrm{~m}$ during the wet season, (c) $N_{\mathrm{ACC}}$ at 60 and $325 \mathrm{~m}$ during the wet season, (d) $N_{\mathrm{UFP}}$ at 60 and $325 \mathrm{~m}$ during the dry season, (e) $N_{\mathrm{AIT}}$ at 60 and $325 \mathrm{~m}$ during the dry season, and (f) $N_{\mathrm{ACC}}$ at 60 and $325 \mathrm{~m}$ during the dry season. 
advected to higher levels, or the dilution due to the growth of the well-mixed BL could be the reason for such a decrease with height. When the sun rises, $N_{\text {UFP }}$ decreases, likely by growth into the Aitken mode particle range, reducing $N_{\mathrm{UPP}}$ in the BL where the concentrations of the Aitken and accumulation mode particles are higher than those in the free troposphere (Schulz et al., 2018).

Another interesting feature is the high variability of the rate of change of particle concentrations. It is clear that the variability is in the frequency of hours, indicating pulses of increase/decrease in the rate of change in the number concentration. This intradiurnal oscillation observed in the rate of change of particle concentrations could be associated with the intradiurnal oscillation of the cloud cover. One of the main forcings of intradiurnal oscillation is the gravity waves. In the next section, we will explore the cloud modulation as well as the downdrafts and updrafts in this range of hundreds of minutes.

\subsection{Cloud intradiurnal variability}

The increase in UFP during convective events could result from new particle formation due to the increase of nitrogen oxides, ozone and ions produced by the lightning discharges or by the vertical advection of UFP from upper levels. Both processes depend on the cloud dynamics, such as the downdraft/updraft intensity and frequency. Therefore, evaluating the cloud variability and what drives these oscillations is an important aspect of understanding how weather events modify PSD. Another aspect is the rate of change of the particle number concentration, in all modes, in response to weather events. It shows a well-marked oscillation of the order of hundreds of minutes with positive and negative rates at both heights. These successive pulses observed in Fig. 9, here nominated as intradiurnal oscillation, could be the result of a series of updrafts and downdrafts or clear/cloud sky in a time interval of the order of hundreds of minutes. A specific analysis was performed to investigate this behavior. The main goal of this analysis is to verify if the cloud cover time evolution has variability in this time range. In a region with smooth topography and homogeneous surface conditions, the forcing and trigger mechanisms of gravity waves produced by convective towers could be the reason for this intradiurnal variability observed in the rate of change of the particle number concentrations.

Gravity waves modulate the deep convection, and at the same time, deep convection produces gravity waves that will modulate convection far away from the source. Lane and Zhang (2011) show that gravity waves control the variability of convective clouds. Vertical propagation of gravity waves produced by convective towers has an important effect on cloud variability (Alexander et al., 1995). In addition, strong updrafts induce tropopause fluctuations that are spread throughout the troposphere and latent heat release due to convection and interactions with the mean flow produce gravity waves (Grimsdell et al., 2010). Wang (2007) observed plume formation above thunderstorm anvils, and in simulating this case, they observed high instability and breaking of the gravity waves excited by the strong convection inside the storm. Using the day/night band from the Suomi National Polarorbiting Partnership (NPP) satellite, Miller et al. (2015) show several examples of thunderstorms triggering a broad spectrum of gravity waves.

Wavelet transforms were employed to evaluate if cloud cover variability has the same pattern as the rate of change of the particle number concentrations. The wavelet transform provides information about the time and the frequency, making it possible to evaluate the amplitude of a specific frequency range in time, and in this case, every $10 \mathrm{~min}$. This methodology will create a time series of the amplitude of the frequencies in intervals with a range of $1-5 \mathrm{~h}$. The Morlet wavelet was applied to a frequency of $T_{\mathrm{IR}}<284 \mathrm{~K}$, to account for the variability of the total cloud cover. The variability in $1-5 \mathrm{~h}$ was integrated and produced a $10 \mathrm{~min}$ time series; the higher values of this time series were used as a proxy of high cloud oscillation in the interval of $1-5 \mathrm{~h}$. Like the composite studies employed in this study, we compute the maximum interdiurnal activity and perform composite studies.

Figure 10a shows the intradiurnal composite for the echo top and lightning density. We can see the high variability of the convection with a succession of moments of more intense convection, with a peak of lightning followed by a higher cloud top. Figure 10b shows the composite for the parameters describing the cloud variability, $T_{\mathrm{IR}}$ and the frequencies of occurrence $T_{\mathrm{IR}}<245 \mathrm{~K}$, a proxy for convective cloud cover, and $T_{\mathrm{IR}}<284 \mathrm{~K}$, a proxy for total cloud cover. This figure describes a typical variability in this frequency range. Convection in Amazonia, forced by this timescale, controls the intracloud or intercloud variability and consequently the addition or loss of particles. During thunderstorms, the updrafts advect particles upward, followed by downdrafts advecting cloud content to the surface. This implies particle modulation by in-cloud scavenging of BL particles and by the downdraft bringing air rich in oxidants and/or UFP to the BL. This intermittent series of updrafts/downdrafts modifies the particles in the BL through a rich spectrum of processes, dominated by UFP enhancement and reduction of $N_{\mathrm{AIT}}$ and $N_{\mathrm{ACC}}$ that occur hundreds of minutes before and after the maximum convective events, not continuously but in a highvariability environment.

\section{Discussion}

In the Introduction, we referred to a large set of studies discussing aerosol-cloud-precipitation interactions. The present research brings new features to complement conceptual models of the effects of weather events on particle size distributions and vice versa in the Amazonian region. How- 

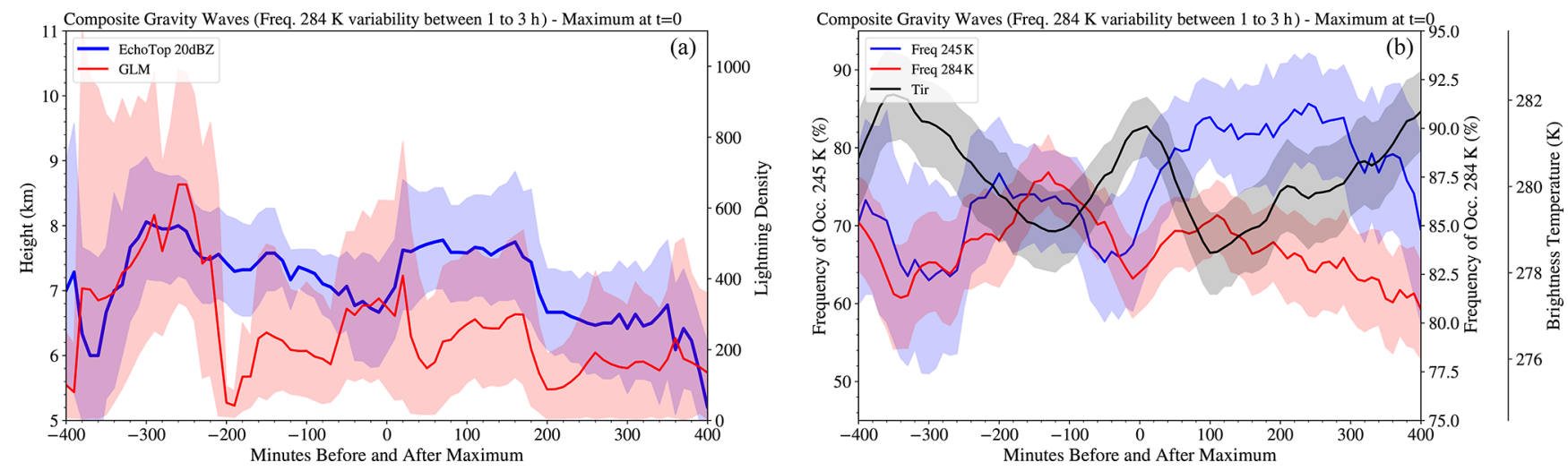

Figure 10. Composite at $400 \mathrm{~min}$ before and after the maximum of variability in the frequency interval from 1 to $5 \mathrm{~h}$ of the total cloud cover ( $T_{\mathrm{IR}}<284 \mathrm{~K}$ ). (a) Echo top and lightning density. (b) $T_{\mathrm{IR}}$, frequency of occurrence of $T_{\mathrm{IR}}<245 \mathrm{~K}$ and $T_{\mathrm{IR}}<284 \mathrm{~K}$ in the area of 12 by $12 \mathrm{~km}^{2}$. The shaded area corresponds to a confidence interval of $95 \%$.

ever, several important questions are still open, and further studies are needed to develop a coherent conceptual model. This section will present some of the well-known processes, adding the new findings from the current investigation and putting in evidence other questions that are fully open.

One of the open questions is related to the source of UFPs in the BL that nearly double in concentration during convective events. On the one hand, recent results show high concentrations of ultrafine particles in the upper troposphere (UT), although the formation processes are still unknown. Wang et al. (2016) described, for case studies, the phenomenon of sharply increasing $N_{\mathrm{UFP}}$ and the simultaneous decrease in the $N_{\mathrm{AIT}}$ and $N_{\mathrm{ACC}}$ during rainfall events, in agreement with the composite studies presented in this study. They showed high concentrations of UFPs in the free troposphere, increasing with height, and proposed that convective downdrafts bring down UFPs from the free troposphere into the BL. On the other hand, they suggest that these particles arise from new particle formation in the outflow regions of deep convective systems, followed by condensation and coagulation growth. Andreae et al. (2018) described the high concentrations of UFP in the UT based on the ACRIDICONCHUVA campaign. They suggested that downdrafts transport these particles to grow into new $\mathrm{CCN}$ in the PBL by VOC oxidation and growth processes. However, downdrafts from deep convection are expected to occur preferentially below the $10-14 \mathrm{~km}$, layer of the source of high concentration of UFP. To evaluate this hypothesis, we analyzed the vertical velocity profile inside the clouds at the ATTO-Campina site. With the new radar wind profile, we have computed a statistical analysis of the vertical velocity. Figure 11 shows the contoured frequency by altitude diagram of the resultant vertical velocity for the thunderstorms season (October-November); therefore, it describes the period of maximum extension of the updraft vertical distribution. The instrument measures the vertical movement of the rain drops, which is a combination of the droplet terminal velocity and air vertical motion. To provide a reference of the expected droplet terminal velocity, Martins et al. (2010) discuss rain droplets in the Amazonian region and mention peaks of $0.5,1.0$ and $2.0 \mathrm{~mm}$ size distributions for rainfall events, which approximately corresponds to a terminal velocity between 4 and $7 \mathrm{~ms}^{-1}$. However, the main feature to be explored in Fig. 11 is not the absolute value of the air vertical velocity, but the layer on which the vertical velocity acts. Figure 11 shows that downdrafts are mostly located below $10 \mathrm{~km}$, but the layer of maximum concentration of UFP is mainly above $10 \mathrm{~km}$. Wang et al. (2018) computed the vertical velocity distribution for convective and stratiform clouds for the GoAmazon and confirm weaker composite vertical air velocity above $10 \mathrm{~km}$. Therefore, the UFPs are more prone to be advected through the Hadley and Walker cells to middle latitudes than to return to the surface tropics as discussed in Kida (1983) using a Lagrangian general circulation model of air parcels. However, the concentration of UFP in the upper troposphere is very high, order of magnitudes more elevated than the surface UFPs. Therefore, even if the maximum downdraft is below the layer of maximum concentration, the small fraction advected downward, below $10 \mathrm{~km}$, could be enough to be the source of UFP particles at the surface during rainfall events.

On the other hand, the biogenic volatile organic compounds produced by forests undergo oxidation reactions to form secondary organic aerosol (SOA) further, and SOA accounts for a substantial fraction of tropospheric aerosol in the Amazon. Pfannerstill et al. (2021) show an increase in $\mathrm{OH}$ reactivity during rain events. The $\mathrm{OH}$ reactivity spikes have similar behavior to the spikes of UFPs during lightning events, and $\mathrm{OH}$ is an efficient mechanism to oxidize the biogenic volatile organic compounds and further form new particles in the BL. The mechanisms effectively describing the processes between rainfall events, the UFP in the upper troposphere and the SOA formation close to the surface should be investigated to clarify these aspects. 
If the new particle formation from thunderstorm events presents this myriad of processes from the UFP in the upper troposphere to the VOC production by the forest, the daily cycle of new particle formation appears to be very clear. There is a typical diurnal cycle behavior; $N_{\text {UFP }}$ exhibits a maximum concentration during the night, and as soon as the sun rises and the convective BL is built, conversion processes to Aitken and accumulation begin, and particle growth occurs up to the time that convection is initiated. Franco et al. (2021) studied ultrafine particle growth and found the most frequent starting cases approximately at twilight time before the convective $\mathrm{BL}$ is developed. Consequently, there is likely a combination of effects, such as the photochemical effect that begins the processes of UFP growing into the Aitken particle size range and the development of the convective BL that contributes to the dynamics of the aerosol (upward advection). In the late afternoon, larger particles start to decrease by rainout, scavenging and updraft removal. This process of increasing UFP and decreasing Aitken and accumulation particles occurs over a large range of variability with successive rain cells, updrafts and downdrafts, controlled by the gravity waves. The rainfall scavenges the larger particles, and the associated downdraft contributes to the increase in $N_{\mathrm{UFP}}$.

Related to the seasonal variation, one can note that in the wet season the weather-PSD interaction is stronger than in the dry season. For instance, for the diurnal cycle, the percentage of relative variability of $N_{\mathrm{UFP}}$ is similar, but the consequent effect on $N_{\mathrm{ACC}}$ is only observed during the wet season. It could be associated with the reduction of concentration during the night followed by a growth process from UFP to accumulation mode particles, in the early morning, that is around $30 \%$ in the wet season and nearly imperceptible in the dry season due to the very high absolute concentration of accumulation mode particles in the dry season. Also, related to the effect of lightning on PSD, the effect during the dry season is small and shows a small difference among the different types of rainfall events (storm, thunderstorm, cloud top height, total liquid water). The dry season is the maximum lightning activity season, but it is in the wet season that a relationship between lightning and $N_{\text {ACC }}(150 \mathrm{~min}$ before the maximum lightning event) is observed. Hernández Pardo et al. (2021), using observation and modeling for Amazonian clouds, concluded that the width of the cloud droplet size distribution for clean clouds (aerosol concentration $<900 \mathrm{~cm}^{-3}$ ) varies as function of the adiabaticity of the cloud. However, for polluted clouds (aerosol concentration $>2000 \mathrm{~cm}^{-3}$ ), the distribution width is not a function of the adiabaticity and varies very little. There are clear differences between the seasons as shown in the present study; the high concentration of particles during the dry season is relatively less sensitive to weather conditions than during the wet season, with lower aerosol concentrations, when the different types of weather events dominate the weather-PSD interactions.

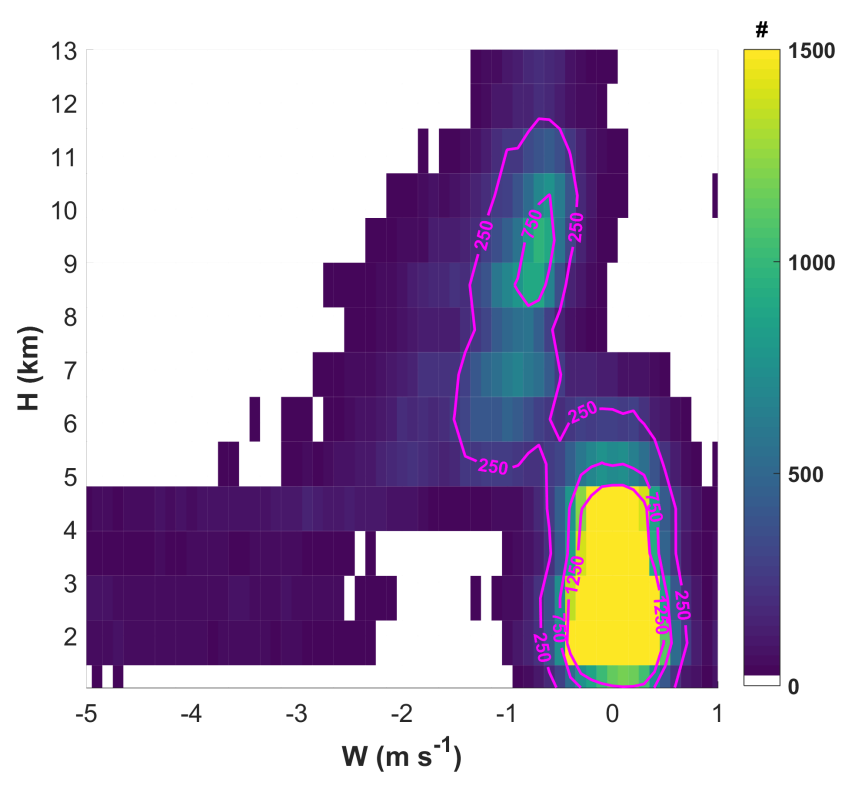

Figure 11. Contoured frequency by altitude diagram of the vertical velocity $W$ obtained by the RWP collected during $54 \mathrm{~d}$ of measurements between 16 October and 8 December 2020. The vertical resolution is $840 \mathrm{~m}$, while the $W$ resolution is $0.1 \mathrm{~m} \mathrm{~s}^{-1}$. The contours show the number of data points (magenta curves).

\section{Conclusions}

Particle size distribution data from two SMPS instruments at ATTO at 60 and $325 \mathrm{~m}$ were combined with satellite and radar data to provide the basis for exploring the relationship between weather events and changes in particle size distributions in the BL of the central Amazon forest. A colocated time series for ATTO at 10 min resolution was produced, combining the different types of measurements. Several features describing the evolution of the particle size distribution could be observed for different weather cycles, forcings and characteristics.

The seasonality is pronounced, with particle concentrations in the dry season being an order of magnitude greater than those during the wet season, and the brightness temperature followed this behavior, with colder brightness temperatures during the wet season (cold cloud tops) than during the dry season. However, lightning has a completely different behavior, and the transition season is the period where the maximum lightning activity is observed.

The diurnal cycle shows a typical behavior with nearly the same phase in both seasons. The maximum concentration of UFP is observed at sunrise, and at this time, $N_{\mathrm{AIT}}$ and $N_{\mathrm{ACC}}$ present a minimum. As the sun rises and the convective BL develops, the UFPs begin to show a decrease in the number concentration followed by an increase in $N_{\text {AIT }}$ and $N_{\text {ACC }}$, with a typical behavior of growth in the particle size. At the end of the afternoon, an inverse situation occurs, and $N_{\mathrm{AIT}}$ and $N_{\text {ACC }}$ decrease while $N_{\text {UFP }}$ increases due to the more 
intense rainfall. Despite the higher concentration of accumulation particles, it is $N_{\text {UFP }}$ that has the larger relative amplitude, except during the wet season in which the concentration of accumulation particles mode also has a significant relative variation.

The composite with the lightning activity describes the typical characteristics of the evolution of particle size changes due to convective rainfall. At approximately $100 \mathrm{~min}$ before and $200 \mathrm{~min}$ after the maximum lightning activity, $N_{\text {UFP }}$ increases and Aitken and accumulation particles decrease. Another interesting property is the larger number of lightning events when the aerosol background is higher, which appears to be an indication of convective cloud invigoration.

The same behavior as for lightning is observed in the composites of the echo top, rain rate (reflectivity at $3 \mathrm{~km}$ ), integrated cloud liquid water (VIL) and brightness temperature $\left(T_{\mathrm{IR}}\right)$. Notably, a different behavior is observed between wet and dry seasons. During the wet season, lightning correlates with a greater change in the particle size distribution in comparison with the dry season for the other weather parameters. This feature should be investigated in future campaigns to explain the reasons for this large sensitivity during the wet season. It seems that for small aerosol concentrations, weatherPSD interaction is dominated by the weather events; however, during the dry season this interaction is dominated by the total aerosol concentration.

The interdiurnal variability modulates the convective activity and produces a high variability at hourly timescales, making the particle size distribution evolution much more complex and controlling the succession of rain cells, updrafts and downdrafts. The increase of UFP and reduction of Aitken and accumulation mode particles is modulated by a secession of updrafts/downdrafts and cloud types.

Finally, the vertical distribution of the vertical velocity was computed using the radar wind profiler at the ATTOCampina site. The data were collected in the season of the most intense convective activity (October-December) and show that downdrafts are mainly located below $10 \mathrm{~km}$, while the layer of maximum concentration of UFP is mainly above $10 \mathrm{~km}$. However, if even a fraction of UFPs from the middle levels of the troposphere are advected downward, it could support the concentration of UFPs in the surface observed during convective events. $N_{\text {UFP }}$ in the upper troposphere is several orders of magnitude higher than at the surface, but in the middle level of the atmosphere, there is still have a concentration of UFPs larger than in the surface. However, the source of the UFPs at the surface during convective events is still an open question because there is also the mechanism of particle formation related to the increase of $\mathrm{OH}$ and $\mathrm{NO}_{x}$ during convective events.

This study clarifies the processes related to modulation of PSD and new particle formation associated with the seasonal and diurnal cycle, intradiurnal variability, and different types and characteristics of convective events. But it opens up fur- ther questions that need to be pursued in detail in new field campaigns, such as CAFE-Brazil scheduled for 2022 and the new ATTO-Campina site that provides measurements of atmospheric and cloud physical properties.

Code and data availability. Goes-16, GLM and SIPAM radar collocated to ATTO data and the main codes used in this study can be found on the portal https://edmond.mpdl.mpg.de/imeji/ collection/Q9NOaAlgWZTq7f9s (Machado, 2021). For data or codes request beyond the available data, please refer to the corresponding authors.

Author contributions. LATM conceptualized this study, conducted the data analysis and wrote the paper. MAF, LAK, FD and BAH conducted the SMPS measurements at ATTO and took care of the data quality checks and processing. MLP, PA and SW supported the ATTO measurements and data analysis. MAC contributed with the LAP3000 data treatment and analysis. MOA, UP and CP contributed to the interpretation of the data and finalization of the paper in various discussions. All the authors contributed to the interpretation of the results and writing of the paper.

Competing interests. Some authors are members of the editorial board of Atmospheric Chemistry and Physics. The peer-review process was guided by an independent editor, and the authors have also no other competing interests to declare.

Disclaimer. Publisher's note: Copernicus Publications remains neutral with regard to jurisdictional claims in published maps and institutional affiliations.

Acknowledgements. This research has been supported by the Max Planck Society, the FAPESP grant 2017/17047-0, the Bundesministerium für Bildung und Forschung (BMBF contracts 01LB1001A, 01LK1602B, and 01LK2101B), and the Max Planck Graduate Center with the Johannes Gutenberg University Mainz (MPGC). For the operation of the ATTO site, we acknowledge the support of the Max Planck Society, the German Federal Ministry of Education and Research, and the Brazilian Ministério da Ciência, Tecnologia e Inovação as well as the Amazon State University (UEA), FAPEAM, LBA/INPA, and SDS/CEUC/RDS-Uatumã. MAF acknowledges CNPq PhD grants 169842/2017-7, and CAPES 88887.368025/2019-00. Micael A. Cecchini was supported by FAPESP grant 2020/132739. We would like to especially thank all the people involved in the technical, logistical and scientific support of the ATTO project, in particular Susan Trumbore, Carlos Alberto Quesada, Reiner Ditz, Jürgen Kesselmeier, Thomas Klimach, Björn Nillius, Antonio O. Manzi, Thomas Disper, Hermes Braga Xavier, Nagib Alberto de Castro Souza, Adir Vasconcelos Brandão, Amauri Rodriguês Perreira, André Luiz Matos, Fábio Jorge, Fernando Goncalves Morais, Roberta Pereira de Souza, Bruno Takeshi, Uwe Schultz, Karl Kübler, Olaf Kolle, Martin Hertel, Kerstin Hip- 
pler and Steffen Schmidt. In particular, we would like to thank Delano Campos, Andrew Crozier, Sam Jones, Juarez Viegas, Wallace Rabelo Costa and Antonio Huxley Melo Nascimento for the frequent maintenance and troubleshooting of the ATTO instruments. We would like to thank the comments and recommendations of the two anonymous reviewers.

Financial support. This research has been supported by the Max Planck Society and the Bundesministerium für Bildung und Forschung (BMBF contracts 01LB1001A, 01LK1602B, and 01LK2101B) and FAPESP (Fundação de Amparo à Pesquisa do Estado de São Paulo, grant no. 2017/17047-0).

The article processing charges for this open-access publication were covered by the Max Planck Society.

Review statement. This paper was edited by Ken Carslaw and reviewed by two anonymous referees.

\section{References}

Adler, R. F. and Mack, R. A.: Thunderstorm Cloud Top Dynamics as Inferred from Satellite Observations and a Cloud Top Parcel Model, J. Atmos. Sci., 43, 1945-1960, https://doi.org/10.1175/15200469(1986)043<1945:TCTDAI>2.0.CO;2, 1986.

Albrecht, B. A.: Aerosols, Cloud Microphysics, and Fractional Cloudiness, Science, 245, 1227-1230, https://doi.org/10.1126/science.245.4923.1227, 1989.

Alexander, M. J., Holton, J. R., and Durran, D. R.: The Gravity Wave Response above Deep Convection in a Squall Line Simulation, J. Atmos. Sci., 52, 2212-2226, https://doi.org/10.1175/15200469(1995)052<2212:TGWRAD>2.0.CO;2, 1995.

Anber, U., Gentine, P., Wang, S., and Sobel, A. H.: Fog and rain in the Amazon, P. Natl. Acad. Sci. USA, 112, 11473-11477, https://doi.org/10.1073/pnas.1505077112, 2015.

Andreae, M. O.: Correlation between cloud condensation nuclei concentration and aerosol optical thickness in remote and polluted regions, Atmos. Chem. Phys., 9, 543-556, https://doi.org/10.5194/acp-9-543-2009, 2009.

Andreae, M. O., Rosenfeld, D., Artaxo, P., Costa, A. A., Frank, G. P., Longo, K. M., and Silva-Dias, M. A. F.: Smoking Rain Clouds over the Amazon, Science, 303, 1337-1342, https://doi.org/10.1126/science.1092779, 2004.

Andreae, M. O., Acevedo, O. C., Araùjo, A., Artaxo, P., Barbosa, C. G. G., Barbosa, H. M. J., Brito, J., Carbone, S., Chi, X., Cintra, B. B. L., da Silva, N. F., Dias, N. L., Dias-Júnior, C. Q., Ditas, F., Ditz, R., Godoi, A. F. L., Godoi, R. H. M., Heimann, M., Hoffmann, T., Kesselmeier, J., Könemann, T., Krüger, M. L., Lavric, J. V., Manzi, A. O., Lopes, A. P., Martins, D. L., Mikhailov, E. F., Moran-Zuloaga, D., Nelson, B. W., Nölscher, A. C., Santos Nogueira, D., Piedade, M. T. F., Pöhlker, C., Pöschl, U., Quesada, C. A., Rizzo, L. V., Ro, C.-U., Ruckteschler, N., Sá, L. D. A., de Oliveira Sá, M., Sales, C. B., dos Santos, R. M. N., Saturno, J., Schöngart, J., Sörgel, M., de Souza, C. M., de Souza,
R. A. F., Su, H., Targhetta, N., Tóta, J., Trebs, I., Trumbore, S., van Eijck, A., Walter, D., Wang, Z., Weber, B., Williams, J., Winderlich, J., Wittmann, F., Wolff, S., and Yáñez-Serrano, A. M.: The Amazon Tall Tower Observatory (ATTO): overview of pilot measurements on ecosystem ecology, meteorology, trace gases, and aerosols, Atmos. Chem. Phys., 15, 10723-10776, https://doi.org/10.5194/acp-15-10723-2015, 2015.

Andreae, M. O., Afchine, A., Albrecht, R., Holanda, B. A., Artaxo, P., Barbosa, H. M. J., Borrmann, S., Cecchini, M. A., Costa, A., Dollner, M., Fütterer, D., Järvinen, E., Jurkat, T., Klimach, T., Konemann, T., Knote, C., Krämer, M., Krisna, T., Machado, L. A. T., Mertes, S., Minikin, A., Pöhlker, C., Pöhlker, M. L., Pöschl, U., Rosenfeld, D., Sauer, D., Schlager, H., Schnaiter, M., Schneider, J., Schulz, C., Spanu, A., Sperling, V. B., Voigt, C., Walser, A., Wang, J., Weinzierl, B., Wendisch, M., and Ziereis, H.: Aerosol characteristics and particle production in the upper troposphere over the Amazon Basin, Atmos. Chem. Phys., 18, 921-961, https://doi.org/10.5194/acp-18-921-2018, 2018.

Angevine,W. M., Edwards, J. M., Lothon, M., LeMone, M. A., and Osborne, S. R.: Transition Periods in the Diurnally-Varying Atmospheric Boundary Layer Over Land, Bound.-Lay. Meteorol., 177, 205-223, https://doi.org/10.1007/s10546-020-00515-y, 2020.

Betts, A. K., Fuentes, J. D., Garstang, M., and Ball, J. H.: Surface diurnal cycle and boundary layer structure over Rondônia during the rainy season, J. Geophys. Res.-Atmos., 107, LBA 32-1LBA 32-14, https://doi.org/10.1029/2001JD000356, 2002.

Boschat, G., Simmonds, I., Purich, A., Cowan, T., and Pezza, A. B.: On the use of composite analyses to form physical hypotheses: An example from heat wave - SST associations, Sci. Rep.-UK, 6, 29599, https://doi.org/10.1038/srep29599, 2016.

Carneiro, R. G. and Fisch, G.: Observational analysis of the daily cycle of the planetary boundary layer in the central Amazon during a non-El Niño year and El Niño year (GoAmazon project 2014/5), Atmos. Chem. Phys., 20, 5547-5558, https://doi.org/10.5194/acp-20-5547-2020, 2020.

Cecchini, M. A., Machado, L. A. T., Andreae, M. O., Martin, S. T., Albrecht, R. I., Artaxo, P., Barbosa, H. M. J., Borrmann, S., Fütterer, D., Jurkat, T., Mahnke, C., Minikin, A., Molleker, S., Pöhlker, M. L., Pöschl, U., Rosenfeld, D., Voigt, C., Weinzierl, B., and Wendisch, M.: Sensitivities of Amazonian clouds to aerosols and updraft speed, Atmos. Chem. Phys., 17, 1003710050, https://doi.org/10.5194/acp-17-10037-2017, 2017a.

Cecchini, M. A., Machado, L. A. T., Wendisch, M., Costa, A., Krämer, M., Andreae, M. O., Afchine, A., Albrecht, R. I., Artaxo, P., Borrmann, S., Fütterer, D., Klimach, T., Mahnke, C., Martin, S. T., Minikin, A., Molleker, S., Pardo, L. H., Pöhlker, C., Pöhlker, M. L., Pöschl, U., Rosenfeld, D., and Weinzierl, B.: Illustration of microphysical processes in Amazonian deep convective clouds in the gamma phase space: introduction and potential applications, Atmos. Chem. Phys., 17, 14727-14746, https://doi.org/10.5194/acp-17-14727-2017, $2017 \mathrm{~b}$.

Deierling, W. and Petersen, W. A.: Total lightning activity as an indicator of updraft characteristics, J. Geophys. Res.-Atmos., 113, D16210, https://doi.org/10.1029/2007JD009598, 2008.

Fan, J., Rosenfeld, D., Zhang, Y., Giangrande, S. E., Li, Z., Machado, L. A. T., Martin, S. T., Yang, Y., Wang, J., Artaxo, P., Barbosa, H. M. J., Braga, R. C., Comstock, J. M., Feng, Z., Gao, W., Gomes, H. B., Mei, F., Pöhlker, C., Pöhlker, M. L., Pöschl, 
U., and de Souza, R. A. F.: Substantial convection and precipitation enhancements by ultrafine aerosol particles, Science, 359, 411-418, https://doi.org/10.1126/science.aan8461, 2018.

Fisch, G., Tota, J., Machado, L. A. T., Silva Dias, M. A. F., da F. Lyra, R. F., Nobre, C. A., Dolman, A. J., and Gash, J. H. C.: The convective boundary layer over pasture and forest in Amazonia, Theoretical and Applied Climatology, 78, 47-59, https://doi.org/10.1007/s00704-004-0043-x, 2004.

Franco, M. A., Ditas, F., Kremper, L. A., Machado, L. A. T., Andreae, M. O., Araújo, A., Barbosa, H. M. J., de Brito, J. F., Carbone, S., Holanda, B. A., Morais, F. G., Nascimento, J. P., Pöhlker, M. L., Rizzo, L. V., Sá, M., Saturno, J., Walter, D., Wolff, S., Pöschl, U., Artaxo, P., and Pöhlker, C.: Occurrence and growth of sub-50 $\mathrm{nm}$ aerosol particles in the Amazonian boundary layer, Atmos. Chem. Phys. Discuss. [preprint], https://doi.org/10.5194/acp-2021-765, in review, 2021.

Gerken, T., Wei, D., Chase, R. J., Fuentes, J. D., Schumacher, C., Machado, L. A., Andreoli, R. V., Chamecki, M., Ferreira de Souza, R. A., Freire, L. S., Jardine, A. B., Manzi, A. O., Nascimento dos Santos, R. M., von Randow, C., dos Santos Costa, P., Stoy, P. C., Tóta, J., and Trowbridge, A. M.: Downward transport of ozone rich air and implications for atmospheric chemistry in the Amazon rainforest, Atmos. Environ., 124, 64-76, https://doi.org/10.1016/j.atmosenv.2015.11.014, 2016.

Giangrande, S. E., Feng, Z., Jensen, M. P., Comstock, J. M., Johnson, K. L., Toto, T., Wang, M., Burleyson, C., Bharadwaj, N., Mei, F., Machado, L. A. T., Manzi, A. O., Xie, S., Tang, S., Silva Dias, M. A. F., de Souza, R. A. F., Schumacher, C., and Martin, S. T.: Cloud characteristics, thermodynamic controls and radiative impacts during the Observations and Modeling of the Green Ocean Amazon (GoAmazon2014/5) experiment, Atmos. Chem. Phys., 17, 14519-14541, https://doi.org/10.5194/acp-17-145192017, 2017.

Goodman, S. J., Blakeslee, R. J., Koshak, W. J., Mach, D., Bailey, J., Buechler, D., Carey, L., Schultz, C., Bateman, M., McCaul, E., and Stano, G.: The GOES-R Geostationary Lightning Mapper (GLM), Atmos. Res., 125-126, 34-49, https://doi.org/10.1016/j.atmosres.2013.01.006, 2013.

Greene, D. R. and Clark, R. A.: Vertically Integrated Liquid Water - A New Analysis Tool, Mon. Weather Rev., $\quad 100, \quad 548-552, \quad$ https://doi.org/10.1175/15200493(1972)100<0548:VILWNA>2.3.CO;2, 1972.

Grimsdell, A. W., Alexander, M. J., May, P. T., and Hoffmann, L.: Model Study of Waves Generated by Convection with Direct Validation via Satellite, J. Atmos. Sci., 67, 1617-1631, https://doi.org/10.1175/2009JAS3197.1, 2010.

Hansen, J., Sato, M., and Ruedy, R.: Radiative forcing and climate response, J. Geophys. Res.-Atmos., 102, 6831-6864, https://doi.org/10.1029/96JD03436, 1997.

Haywood, J. and Boucher, O.: Estimates of the direct and indirect radiative forcing due to tropospheric aerosols: A review, Rev. Geophys., 38, 513-543, https://doi.org/10.1029/1999RG000078, 2000.

Heikenfeld, M., White, B., Labbouz, L., and Stier, P.: Aerosol effects on deep convection: the propagation of aerosol perturbations through convective cloud microphysics, Atmos. Chem. Phys., 19, 2601-2627, https://doi.org/10.5194/acp-192601-2019, 2019.
Henkes, A., Fisch, G., Machado, L. A. T., and Chaboureau, J.-P.: Morning boundary layer conditions for shallow to deep convective cloud evolution during the dry season in the central Amazon, Atmos. Chem. Phys., 21, 13207-13225, https://doi.org/10.5194/acp-21-13207-2021, 2021.

Hernández Pardo, L., Machado, L. A. T., Morrison, H., Cecchini, M. A., Andreae, M. O., Pöhlker, C., Pöschl, U., Rosenfeld, D., Vendrasco, E. P., Voigt, C., Wendisch, M., and Pöhlker, M. L.: Observed and Simulated Variability of Droplet Spectral Dispersion in Convective Clouds Over the Amazon, J. Geophys. Res.-Atmos., 126, e2021JD035076, https://doi.org/10.1029/2021JD035076, 2021.

Holanda, B. A., Pöhlker, M. L., Walter, D., Saturno, J., Sörgel, M., Ditas, J., Ditas, F., Schulz, C., Franco, M. A., Wang, Q., Donth, T., Artaxo, P., Barbosa, H. M. J., Borrmann, S., Braga, R., Brito, J., Cheng, Y., Dollner, M., Kaiser, J. W., Klimach, T., Knote, C., Krüger, O. O., Fütterer, D., Lavrič, J. V., Ma, N., Machado, L. A. T., Ming, J., Morais, F. G., Paulsen, H., Sauer, D., Schlager, H., Schneider, J., Su, H., Weinzierl, B., Walser, A., Wendisch, M., Ziereis, H., Zöger, M., Pöschl, U., Andreae, M. O., and Pöhlker, C.: Influx of African biomass burning aerosol during the Amazonian dry season through layered transatlantic transport of black carbon-rich smoke, Atmos. Chem. Phys., 20, 4757-4785, https://doi.org/10.5194/acp-20-4757-2020, 2020.

Hoppel, W. A., Frick, G. M., and Fitzgerald, J. W.: Deducing droplet concentration and supersaturation in marine boundary layer clouds from surface aerosol measurements, J. Geophys. Res.Atmos., 101, 26553-26565, https://doi.org/10.1029/96JD02243, 1996.

IPCC: Summary for Policymakers, book section SPM, p. 1-30, Cambridge University Press, Cambridge, United Kingdom and New York, NY, USA, https://doi.org/10.1017/CBO9781107415324.004, 2013.

Jadhav, D. B., Londhe, A. L., and Bose, S.: Observations of $\mathrm{NO}_{2}$ and $\mathrm{O}_{3}$ during thunderstorm activity using visible spectroscopy, Adv. Atmos. Sci., 13, 359-374, https://doi.org/10.1007/BF02656853, 1996.

Junk, W. J., Piedade, M. T. F., Schöngart, J., Cohn-Haft, M., Adeney, J. M., and Wittmann, F.: A classification of major naturally-occurring Amazonian lowland wetlands, Wetlands, 31, 623-640, 2011.

Kida, H.: General Circulation of Air Parcels and Transport Characteristics Derived from a Hemispheric GCM, J. Meteorol. Soc. Jpn., 61, 510-523, https://doi.org/10.2151/jmsj1965.61.4_510, 1983.

Koren, I., Kaufman, Y. J., Rosenfeld, D., Remer, L. A., and Rudich, Y.: Aerosol invigoration and restructuring of Atlantic convective clouds, Geophys. Res. Lett., 32, L14828, https://doi.org/10.1029/2005GL023187, 2005.

Lane, T. P. and Zhang, F.: Coupling between Gravity Waves and Tropical Convection at Mesoscales, J. Atmos. Sci., 68, 25822598, https://doi.org/10.1175/2011JAS3577.1, 2011.

Leppla, D., Zannoni, N., Kremper, L., Williams, J., Pöhlker, C., Sá, M., Solci, M. C., and Hoffmann, T.: Varying chiral ratio of Pinic acid enantiomers above the Amazon rainforest, Atmos. Chem. Phys. Discuss. [preprint], https://doi.org/10.5194/acp-2021-150, 2021. 
Machado, L. A. T.: Data Used for ACP 2021-314, Max Planck Society, available at: https://edmond.mpdl.mpg.de/imeji/collection/ Q9NOaAlgWZTq7f9s, last access: 9 December 2021.

Machado, L. A. T. and Rossow, W. B.: Structural Characteristics and Radiative Properties of Tropical Cloud Clusters, Mon. Weather Rev., 121, 3234-3260, https://doi.org/10.1175/15200493(1993)121<3234:SCARPO>2.0.CO;2, 1993.

Machado, L. A. T., Laurent, H., and Lima, A. A.: Diurnal march of the convection observed during TRMMWETAMC/LBA, J. Geophys. Res.-Atmos., 107, LBA 31-1LBA 31-15, https://doi.org/10.1029/2001JD000338, 2002.

Machado, L. A. T., Laurent, H., Dessay, N., and Miranda, I.: Seasonal and diurnal variability of convection over the Amazonia: A comparison of different vegetation types and large scale forcing, Theoretical and Applied Climatology, 78, 61-77, https://doi.org/10.1007/s00704-004-0044-9, 2004.

Machado, L. A. T., Calheiros, A. J. P., Biscaro, T., Giangrande, S., Silva Dias, M. A. F., Cecchini, M. A., Albrecht, R., Andreae, M. O., Araujo, W. F., Artaxo, P., Borrmann, S., Braga, R., Burleyson, C., Eichholz, C. W., Fan, J., Feng, Z., Fisch, G. F., Jensen, M. P., Martin, S. T., Pöschl, U., Pöhlker, C., Pöhlker, M. L., Ribaud, J.-F., Rosenfeld, D., Saraiva, J. M. B., Schumacher, C., Thalman, R., Walter, D., and Wendisch, M.: Overview: Precipitation characteristics and sensitivities to environmental conditions during GoAmazon2014/5 and ACRIDICON-CHUVA, Atmos. Chem. Phys., 18, 6461-6482, https://doi.org/10.5194/acp18-6461-2018, 2018.

Martin, S. T., Andreae, M. O., Althausen, D., Artaxo, P., Baars, H., Borrmann, S., Chen, Q., Farmer, D. K., Guenther, A., Gunthe, S. S., Jimenez, J. L., Karl, T., Longo, K., Manzi, A., Müller, T., Pauliquevis, T., Petters, M. D., Prenni, A. J., Pöschl, U., Rizzo, L. V., Schneider, J., Smith, J. N., Swietlicki, E., Tota, J., Wang, J., Wiedensohler, A., and Zorn, S. R.: An overview of the Amazonian Aerosol Characterization Experiment 2008 (AMAZE-08), Atmos. Chem. Phys., 10, 1141511438, https://doi.org/10.5194/acp-10-11415-2010, 2010.

Martin, S. T., Artaxo, P., Machado, L. A. T., Manzi, A. O., Souza, R. A. F., Schumacher, C., Wang, J., Andreae, M. O., Barbosa, H. M. J., Fan, J., Fisch, G., Goldstein, A. H., Guenther, A., Jimenez, J. L., Pöschl, U., Silva Dias, M. A., Smith, J. N., and Wendisch, M.: Introduction: Observations and Modeling of the Green Ocean Amazon (GoAmazon2014/5), Atmos. Chem. Phys., 16, 47854797, https://doi.org/10.5194/acp-16-4785-2016, 2016.

Martin, S. T., Artaxo, P., Machado, L., Manzi, A. O., Souza, R. A. F., Schumacher, C., Wang, J., Biscaro, T., Brito, J., Calheiros, A., Jardine, K., Medeiros, A., Portela, B., de Sá, S. S., Adachi, K., Aiken, A. C., Albrecht, R., Alexander, L., Andreae, M. O., Barbosa, H. M. J., Buseck, P., Chand, D., Comstock, J. M., Day, D. A., Dubey, M., Fan, J., Fast, J., Fisch, G., Fortner, E., Giangrande, S., Gilles, M., Goldstein, A. H., Guenther, A., Hubbe, J., Jensen, M., Jimenez, J. L., Keutsch, F. N., Kim, S., Kuang, C., Laskin, A., McKinney, K., Mei, F., Miller, M., Nascimento, R., Pauliquevis, T., Pekour, M., Peres, J., Petäjä, T., Pöhlker, C., Pöschl, U., Rizzo, L., Schmid, B., Shilling, J. E., Dias, M. A. S., Smith, J. N., Tomlinson, J. M., Tóta, J., and Wendisch, M.: The Green Ocean Amazon Experiment (GoAmazon2014/5) Observes Pollution Affecting Gases, Aerosols, Clouds, and Rainfall over the Rain Forest, B. Am. Meteorol. Soc., 98, 981-997, https://doi.org/10.1175/BAMS-D-15-00221.1, 2017.
Martins, R. C., Machado, L. A., and Costa, A. A.: Characterization of the microphysics of precipitation over Amazon region using radar and disdrometer data, Atmos. Res., 96, 388-394, https://doi.org/10.1016/j.atmosres.2010.01.011, 2010.

Miller, S. D., Straka, W. C., Yue, J., Smith, S. M., Alexander, M. J., Hoffmann, L., Setvák, M., and Partain, P. T.: Upper atmospheric gravity wave details revealed in nightglow satellite imagery, P. Natl. Acad. Sci. USA, 112, E6728-E6735, https://doi.org/10.1073/pnas.1508084112, 2015.

Moran-Zuloaga, D., Ditas, F., Walter, D., Saturno, J., Brito, J., Carbone, S., Chi, X., Hrabě de Angelis, I., Baars, H., Godoi, R. H. M., Heese, B., Holanda, B. A., Lavrič, J. V., Martin, S. T., Ming, J., Pöhlker, M. L., Ruckteschler, N., Su, H., Wang, Y., Wang, Q., Wang, Z., Weber, B., Wolff, S., Artaxo, P., Pöschl, U., Andreae, M. O., and Pöhlker, C.: Long-term study on coarse mode aerosols in the Amazon rain forest with the frequent intrusion of Saharan dust plumes, Atmos. Chem. Phys., 18, 10055-10088, https://doi.org/10.5194/acp-18-10055-2018, 2018.

Palm, B. B., de Sá, S. S., Day, D. A., Campuzano-Jost, P., Hu, W., Seco, R., Sjostedt, S. J., Park, J.-H., Guenther, A. B., Kim, S., Brito, J., Wurm, F., Artaxo, P., Thalman, R., Wang, J., Yee, L. D., Wernis, R., Isaacman-VanWertz, G., Goldstein, A. H., Liu, Y., Springston, S. R., Souza, R., Newburn, M. K., Alexander, M. L., Martin, S. T., and Jimenez, J. L.: Secondary organic aerosol formation from ambient air in an oxidation flow reactor in central Amazonia, Atmos. Chem. Phys., 18, 467-493, https://doi.org/10.5194/acp-18-467-2018, 2018.

Pfannerstill, E. Y., Reijrink, N. G., Edtbauer, A., Ringsdorf, A., Zannoni, N., Araújo, A., Ditas, F., Holanda, B. A., Sá, M. O., Tsokankunku, A., Walter, D., Wolff, S., Lavrič, J. V., Pöhlker, C., Sörgel, M., and Williams, J.: Total $\mathrm{OH}$ reactivity over the Amazon rainforest: variability with temperature, wind, rain, altitude, time of day, season, and an overall budget closure, Atmos. Chem. Phys., 21, 6231-6256, https://doi.org/10.5194/acp21-6231-2021, 2021.

Pöhlker, M. L., Pöhlker, C., Ditas, F., Klimach, T., Hrabe de Angelis, I., Araújo, A., Brito, J., Carbone, S., Cheng, Y., Chi, X., Ditz, R., Gunthe, S. S., Kesselmeier, J., Könemann, T., Lavrič, J. V., Martin, S. T., Mikhailov, E., Moran-Zuloaga, D., Rose, D., Saturno, J., Su, H., Thalman, R., Walter, D., Wang, J., Wolff, S., Barbosa, H. M. J., Artaxo, P., Andreae, M. O., and Pöschl, U.: Longterm observations of cloud condensation nuclei in the Amazon rain forest - Part 1: Aerosol size distribution, hygroscopicity, and new model parametrizations for CCN prediction, Atmos. Chem. Phys., 16, 15709-15740, https://doi.org/10.5194/acp-16-157092016, 2016.

Pöhlker, M. L., Ditas, F., Saturno, J., Klimach, T., Hrabě de Angelis, I., Araùjo, A. C., Brito, J., Carbone, S., Cheng, Y., Chi, X., Ditz, R., Gunthe, S. S., Holanda, B. A., Kandler, K., Kesselmeier, J., Könemann, T., Krüger, O. O., Lavrič, J. V., Martin, S. T., Mikhailov, E., Moran-Zuloaga, D., Rizzo, L. V., Rose, D., Su, H., Thalman, R., Walter, D., Wang, J., Wolff, S., Barbosa, H. M. J., Artaxo, P., Andreae, M. O., Pöschl, U., and Pöhlker, C.: Long-term observations of cloud condensation nuclei over the Amazon rain forest - Part 2: Variability and characteristics of biomass burning, long-range transport, and pristine rain forest aerosols, Atmos. Chem. Phys., 18, 10289-10331, https://doi.org/10.5194/acp-18-10289-2018, 2018. 
Pöschl, U., Martin, S. T., Sinha, B., Chen, Q., Gunthe, S. S., Huffman, J. A., Borrmann, S., Farmer, D. K., Garland, R. M., Helas, G., Jimenez, J. L., King, S. M., Manzi, A., Mikhailov, E., Pauliquevis, T., Petters, M. D., Prenni, A. J., Roldin, P., Rose, D., Schneider, J., Su, H., Zorn, S. R., Artaxo, P., and Andreae, M. O.: Rainforest Aerosols as Biogenic Nuclei of Clouds and Precipitation in the Amazon, Science, 329, 15131516, https://doi.org/10.1126/science.1191056, 2010.

Ramanathan, V., Crutzen, P. J., Kiehl, J. T., and Rosenfeld, D.: Aerosols, Climate, and the Hydrological Cycle, Science, 294, 2119-2124, https://doi.org/10.1126/science.1064034, 2001.

Rosenfeld, D.: TRMM observed first direct evidence of smoke from forest fires inhibiting rainfall, Geophys. Res. Lett., 26, 31053108, https://doi.org/10.1029/1999GL006066, 1999.

Rosenfeld, D.: Cloud-Aerosol-Precipitation Interactions Based of Satellite Retrieved Vertical Profiles of Cloud Microstructure, chap. 6, in: Remote Sensing of Aerosols, Clouds, and Precipitation, 2018.

Rosenfeld, D., Lohmann, U., Raga, G. B., O'Dowd, C. D., Kulmala, M., Fuzzi, S., Reissell, A., and Andreae, M. O.: Flood or Drought: How Do Aerosols Affect Precipitation?, Science, 321, 1309-1313, https://doi.org/10.1126/science.1160606, 2008.

Saturno, J., Holanda, B. A., Pöhlker, C., Ditas, F., Wang, Q., Moran-Zuloaga, D., Brito, J., Carbone, S., Cheng, Y., Chi, X., Ditas, J., Hoffmann, T., Hrabe de Angelis, I., Könemann, T., Lavrič, J. V., Ma, N., Ming, J., Paulsen, H., Pöhlker, M. L., Rizzo, L. V., Schlag, P., Su, H., Walter, D., Wolff, S., Zhang, Y., Artaxo, P., Pöschl, U., and Andreae, M. O.: Black and brown carbon over central Amazonia: long-term aerosol measurements at the ATTO site, Atmos. Chem. Phys., 18, 1281712843, https://doi.org/10.5194/acp-18-12817-2018, 2018.

Schiro, K. A. and Neelin, J. D.: Tropical continental downdraft characteristics: mesoscale systems versus unorganized convection, Atmos. Chem. Phys., 18, 1997-2010, https://doi.org/10.5194/acp-18-1997-2018, 2018.

Schrod, J., Thomson, E. S., Weber, D., Kossmann, J., Pöhlker, C., Saturno, J., Ditas, F., Artaxo, P., Clouard, V., Saurel, J.-M., Ebert, M., Curtius, J., and Bingemer, H. G.: Long-term deposition and condensation ice-nucleating particle measurements from four stations across the globe, Atmos. Chem. Phys., 20, 1598316006, https://doi.org/10.5194/acp-20-15983-2020, 2020.

Schulz, C., Schneider, J., Amorim Holanda, B., Appel, O., Costa, A., de Sá, S. S., Dreiling, V., Fütterer, D., Jurkat-Witschas, T., Klimach, T., Knote, C., Krämer, M., Martin, S. T., Mertes, S., Pöhlker, M. L., Sauer, D., Voigt, C., Walser, A., Weinzierl, B., Ziereis, H., Zöger, M., Andreae, M. O., Artaxo, P., Machado, L. A. T., Pöschl, U., Wendisch, M., and Borrmann, S.: Aircraftbased observations of isoprene-epoxydiol-derived secondary organic aerosol (IEPOX-SOA) in the tropical upper troposphere over the Amazon region, Atmos. Chem. Phys., 18, 14979-15001, https://doi.org/10.5194/acp-18-14979-2018, 2018.

Stull, R. B.: An Introduction to Boundary Layer Meteorology, Springer, Dordrecht, https://doi.org/10.1007/978-94-009-30278, 1988.

Tridon, F., Battaglia, A., Kollias, P., Luke, E., and Williams, C. R.: Signal Postprocessing and Reflectivity Calibration of the Atmospheric Radiation Measurement Program 915-MHz Wind Profilers, J. Atmos. Ocean. Technol., 30, 1038-1054, https://doi.org/10.1175/JTECH-D-12-00146.1, 2013.
Tuch, T. M., Haudek, A., Müller, T., Nowak, A., Wex, H., and Wiedensohler, A.: Design and performance of an automatic regenerating adsorption aerosol dryer for continuous operation at monitoring sites, Atmos. Meas. Tech., 2, 417-422, https://doi.org/10.5194/amt-2-417-2009, 2009.

Twomey, S. and Warner, J.: Comparison of Measurements of Cloud Droplets and Cloud Nuclei, J. Atmos. Sci., 24, 702-703, https://doi.org/10.1175/15200469(1967)024<0702:COMOCD>2.0.CO;2, 1967.

Varanda Rizzo, L., Roldin, P., Brito, J., Backman, J., Swietlicki, E., Krejci, R., Tunved, P., Petäjä, T., Kulmala, M., and Artaxo, P.: Multi-year statistical and modeling analysis of submicrometer aerosol number size distributions at a rain forest site in Amazonia, Atmos. Chem. Phys., 18, 10255-10274, https://doi.org/10.5194/acp-18-10255-2018, 2018.

von der Weiden, S.-L., Drewnick, F., and Borrmann, S.: Particle Loss Calculator - a new software tool for the assessment of the performance of aerosol inlet systems, Atmos. Meas. Tech., 2, 479-494, https://doi.org/10.5194/amt-2-479-2009, 2009.

Wang, D., Giangrande, S. E., Bartholomew, M. J., Hardin, J., Feng, Z., Thalman, R., and Machado, L. A. T.: The Green Ocean: precipitation insights from the GoAmazon2014/5 experiment, Atmos. Chem. Phys., 18, 9121-9145, https://doi.org/10.5194/acp18-9121-2018, 2018.

Wang, H., Pei, Y., Yin, Y., Shen, L., Chen, K., Shi, Z., and Chen, J.: Observational Evidence of Lightning-Generated U1trafine Aerosols, Geophys. Res. Lett., 48, e2021GL093771, https://doi.org/10.1029/2021GL093771, 2021.

Wang, J., Krejci, R., Giangrande, S., Kuang, C., Barbosa, H. M. J., Brito, J., Carbone, S., Chi, X., Comstock, J., Ditas, F., Lavric, J., Manninen, H. E., Mei, F., Moran-Zuloaga, D., Pöhlker, C., Pöhlker, M. L., Saturno, J., Schmid, B., Souza, R. A. F., Springston, S. R., Tomlinson, J. M., Toto, T., Walter, D., Wimmer, D., Smith, J. N., Kulmala, M., Machado, L. A. T., Artaxo, P., Andreae, M. O., Petäjä, T., and Martin, S. T.: Amazon boundary layer aerosol concentration sustained by vertical transport during rainfall, Nature, 539, 416-419, https://doi.org/10.1038/nature19819, 2016.

Wang, P. K.: The thermodynamic structure atop a penetrating convective thunderstorm, Atmos. Res., 83, 254-262, https://doi.org/10.1016/j.atmosres.2005.08.010, 2007.

Wendisch, M., Pöschl, U., Andreae, M. O., Machado, L. A. T., Albrecht, R., Schlager, H., Rosenfeld, D., Martin, S. T., Abdelmonem, A., Afchine, A., Araùjo, A. C., Artaxo, P., Aufmhoff, H., Barbosa, H. M. J., Borrmann, S., Braga, R., Buchholz, B., Cecchini, M. A., Costa, A., Curtius, J., Dollner, M., Dorf, M., Dreiling, V., Ebert, V., Ehrlich, A., Ewald, F., Fisch, G., Fix, A., Frank, F., Fütterer, D., Heckl, C., Heidelberg, F., Hüneke, T., Jäkel, E., Järvinen, E., Jurkat, T., Kanter, S., Kästner, U., Kenntner, M., Kesselmeier, J., Klimach, T., Knecht, M., Kohl, R., Kölling, T., Krämer, M., Krüger, M., Krisna, T. C., Lavric, J. V., Longo, K., Mahnke, C., Manzi, A. O., Mayer, B., Mertes, S., Minikin, A., Molleker, S., Münch, S., Nillius, B., Pfeilsticker, K., Pöhlker, C., Roiger, A., Rose, D., Rosenow, D., Sauer, D., Schnaiter, M., Schneider, J., Schulz, C., de Souza, R. A. F., Spanu, A., Stock, P., Vila, D., Voigt, C., Walser, A., Walter, D., Weigel, R., Weinzierl, B., Werner, F., Yamasoe, M. A., Ziereis, H., Zinner, T., and Zöger, M.: ACRIDICON-CHUVA Campaign: Studying Tropical Deep Convective Clouds and Precipitation over Amazonia Using the New German Research Aircraft HALO, B. Am. 
Meteorol. Soc., 97, 1885-1908, https://doi.org/10.1175/BAMSD-14-00255.1, 2016.

Williamson, C. J., Kupc, A., Axisa, D., Bilsback, K. R., Bui, T., Campuzano-Jost, P., Dollner, M., Froyd, K. D., Hodshire, A. L., Jimenez, J. L., Kodros, J. K., Luo, G., Murphy, D. M., Nault, B. A., Ray, E. A., Weinzierl, B., Wilson, J. C., Yu, F., Yu, P., Pierce, J. R., and Brock, C. A.: A large source of cloud condensation nuclei from new particle formation in the tropics, Nature, 574, 399-403, https://doi.org/10.1038/s41586-019-1638-9, 2019.

Yuter, S. and Houze, R.: Three-Dimensional Kinematic and Microphysical Evolution of Florida Cumulonimbus. Part II: Frequency Distributions of Vertical Velocity, Reflectivity, and Differential Reflectivity, Mon. Weather Rev., 123, 1941-1963, 1995.
Yáñez-Serrano, A. M., Bourtsoukidis, E., Alves, E. G., Bauwens, M., Stavrakou, T., Llusià, J., Filella, I., Guenther, A., Williams, J., Artaxo, P., Sindelarova, K., Doubalova, J., Kesselmeier, J., and Peñuelas, J.: Amazonian biogenic volatile organic compounds under global change, Glob. Change Biol., 26, 4722-4751, https://doi.org/10.1111/gcb.15185, 2020. 